\title{
Will the Birds Stay South? The Rise of Class Actions and Other Forms of Group Litigation Across Latin America
}

Manuel A. Gómez

Florida International University College of Law, magomez@fiu.edu

Follow this and additional works at: https://ecollections.law.fiu.edu/faculty_publications

Part of the Law Commons

\section{Recommended Citation}

Manuel A. Gómez, Will the Birds Stay South? The Rise of Class Actions and Other Forms of Group Litigation Across Latin America, 3 U. Miami Inter-Am. L. Rev. 43 (2012).

Available at: https://ecollections.law.fiu.edu/faculty_publications/43 


\section{HEINONLINE}

Citation: 43 U. Miami Inter-Am. L. Rev. 481 2011-2012

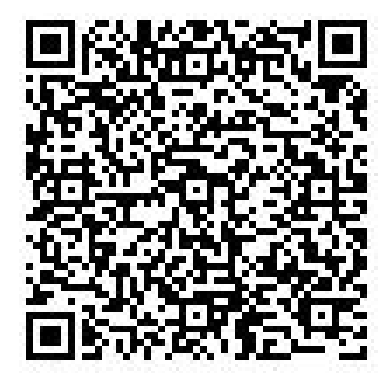

Content downloaded/printed from

HeinOnline (http://heinonline.org)

Thu Oct 9 19:25:42 2014

-- Your use of this HeinOnline PDF indicates your acceptance of HeinOnline's Terms and Conditions of the license agreement available at http://heinonline.org/HOL/License

-- The search text of this PDF is generated from uncorrected OCR text.

-- To obtain permission to use this article beyond the scope of your HeinOnline license, please use:

https://www.copyright.com/ccc/basicSearch.do?

\&operation $=$ go\&search $\mathrm{Type}=0$

\&lastSearch $=$ simple\&all=on\&titleOrStdNo=0884-1756 


\title{
Will the Birds Stay South? The Rise of Class Actions and Other Forms of Group Litigation Across Latin America
}

\author{
Manuel A. Gómez*
}

\section{INTRODUCTION}

The filing of claims by foreign plaintiffs in United States courts has been reported to be on the rise. ${ }^{1}$ The general perception is that foreign claimants have strong incentives to litigate in the United States, ${ }^{2}$ and Latin Americans are not the exception. ${ }^{3}$ Several reasons have been given to explain the rising numbers of foreign claimants in United States courts, including the possibility of

* Associate Professor, Florida International University College of Law. The author wishes to thank Deborah R. Hensler, Christopher Hodges, and his other colleagues at the interdisciplinary research network on global class actions, and participants in the International Conferences on Global Class Actions held at Oxford in 2007 and 2008, and Miami in 2010, for their comments on earlier drafts of this article. He would also like to thank Masayuki Murayama, Luigi Comminelli, Bert Kritzer and other participants at the 2010 Workshop on Dispute Resolution from a Comparative Perspective held at the International Institute for the Sociology of Law in Oñati, Spain. Diana Rodriguez Franco and Beatriz Londoño Toro offered invaluable insight and sources on Colombia. Silvia Kim, Diego Gandolfo, Rosangela Delgado and Vitor Lorenço Simão Castro helped the author learn more about class actions in Brazil. Eugenio Cardenas and Julio Gutierrez Morales helped locate materials on the status of collective litigation in Mexico, and Agustin Barroilhet helped with class actions in Chile. Marisol Floren-Romero offered excellent library support, and FIU College of Law provided financial assistance throughout. This article builds upon previous work published as Manuel A. Gómez, Collective Redress in Latin America: The regulation of class actions and other forms of aggregate and group litigation for the protection of consumer rights, in L'Art. 140 Bis del Codice del Consumo L'Azione di Classe 265-82(Lorenzo Mezzasoma \& Francesco Rizzo, eds. 2011).

1. See Wolfgang Wurmnest, Foreign Private Plaintiffs, Global Conspiracies, and the Extraterritorial Application of U.S. Antitrust Law, 28 Hastings InT'L \& Comp. L. REv. 205, 206 (2004-2005).

2. See, e.g., Manuel A. Gómez, Like Migratory Birds: Latin American Claimants in U.S. Courts and the Ford-Firestone Rollover Litigation, 11 Sw. J. L. \& TRADE AM. 281, 295-97 (2005) (discussing the incentives perceived by South American plaintiffs for litigating in U.S. courts); Smith Kline \& French Lab. Ltd. v. Bloch, [1982] 1 W.L.R. 730, 733 (C.A. 1983) ("As a moth is drawn to the light, so is a litigant drawn to the United States."); David W. Robertson \& Paula K. Speck, Access to State Courts in Transnational Personal Injury Cases: Forum Non Conveniens and Antisuit Injunctions, 68 TEx. L. Rev. 937, 938 (1989-1990) ("Personal injury victims are virtually always better off suing in the United States. ...")

3. See supra note 2. 
obtaining larger awards that contain punitive damages. ${ }^{4}$ Foreign claimants also seem to be attracted by the cost rules prevailing in the United States, under which each party bears its own costs, ${ }^{5}$ thus minimizing the risks of the party that loses the litigation. ${ }^{6} \mathrm{~A}$ related enticement for foreign parties to pursue their claims in United States courts rests on the possibility of retaining counsel on a contingency fee basis, common in the United States but generally proscribed elsewhere. ${ }^{7}$

Another perceived advantage of the United States vis-à-vis most Latin American jurisdictions rests on the availability of class actions and similar procedural devices. ${ }^{8}$ Class actions facilitate the aggregation of numerous small claims against one or several defendants in a single litigation, an outcome that will bind-and thus benefit—not only representative plaintiffs but all class members. ${ }^{9}$ Because many Latin American countries do not allow class actions, citizens of those countries have long relied on pursuing their claims in United States courts, often to obtain redress for harms suffered in their own countries..$^{10}$

Some have criticized the ostensible openness of American courts to foreign plaintiffs by arguing that the increased presence of cases involving foreign parties with no significant connection to the United States congests the American judiciary, uses up valuable resources, and encourages forum shopping. ${ }^{11}$ Conversely, some Latin American jurisdictions have reacted by enacting blocking

4. Cf. Russell J. Weintraub, How Substantial is Our Need for a JudgmentsRecognition Convention and What Should We Bargain Away to Get It? 24 BRoOK. J. INT'L L. 167, $182-83$ (1998); Ilana T. Buschkin, The Viability of Class Action Lawsuits in a Globalized Economy-Permitting Foreign Claimants to be Members of Class Action Lawsuits in the U.S. Federal Courts, 90 CoRnell L. REv. 1563, 1597 (2005).

5. David Boyce, Foreign Plaintiffs and Forum Non Conveniens: Going Beyond Reyno, 64 Tex. L. Rev 193, 197 (1985); Donna Solen, Forum Non Conveniens and the International Plaintiff, 9 Fla. J. Int'l L. 343, 343 (1994).

6. See Thomas D. Rowe Jr, The Legal Theory of Attorney Fee Shifiting: A Critical Overview, 1982 DuKE L.J. 651, 651 (1982).

7. See Sheila Birnbaum \& Douglas W. Dunham, Foreign Plaintiffs and Forum Non Conveniens, 16 Brook. J. InT'L L. 241, 242 (1990); Gómez, supra note 2, at 283; Hebert M. Kritzer, The Wages of Risk: The Returns of Contingency Fee Legal Practice in the United States, 47 DePaul L. Rev. 267, 267 (1998); Mathias Reimann, Liability for Defective Products at the Beginning of the Twenty-First Century: Emergence of a Worldwide Standard? 51 AM. J. CoMP. L. 751, 822 (2003).

8. See Piper Aircraft Co. v. Reyno, 454 U.S. 235, 252 (1981); Birnbaum \& Dunham, supra note 7, at 243.

9. See FED. R. Civ. P. 23.

10. See Gómez, supra note 2, at 283.

11. See Bersch v. Drexel Firestone, Inc., 519 F.2d 974, 998 (2d Cir. 1975); Buschkin, supra note 4, at 1568 n. 25; F. Hoffmann-La Roche v. Empagran S.A., 542 U.S. 155, 167-68 (2004) (citation omitted). 
statutes in an attempt to discourage their own citizens from conveniently choosing to litigate in the United States, instead of using their local courts. ${ }^{12}$

This debate has encouraged different stakeholders, including scholars, ${ }^{13}$ policymakers, consumer protection advocates, plaintiff lawyers, and defense lawyers, ${ }^{14}$ to discuss the possibility of adopting class actions and other forms of group litigation throughout Latin America. At the same time, Latin American judges are receiving requests for judicial protection against collective harms through mechanisms not originally intended for dealing with mass claims,${ }^{15}$ and with the aid of practitioners they have devised creative solutions to remedy situations not previously regulated by statutes. ${ }^{16}$

12. See M. Ryan Casey \& Barrett Ristroph, Boomerang Litigation: How Convenient is Forum Non Conveniens in Transnational Litigation? 4 BYU INT'L L. \& Mngmt. Rev. 21, 21 n. 2 (2007); Ley No. 364, 5 October 2000, Ley Especial para la Tramitación de Juicios Promovidos por las Personas Afectadas por el Uso de Pesticidas Fabricados a Base de DBCP [Special Law for the Conduct of Lawsuits filed by persons affected by the use of pesticides manufactured with a DBCP base] LA Gaceta, Diario Oficial [L.G.] 17 January 2001 (Nicar.); see generally Henry Saint Dahl, Forum Non Conveniens, Latin America and Blocking Statutes, 35 U. MIAMI INTER-AM. L. REV. 21, 22 (2003).

13. See generally Héctor A. Mairal, Argentina, in 622 Annals Am. Acad. Pol. \& Soc. Sci. 54 (2009); see generally Ada Pellegrini Grinover, Brazil, in 622 Annals Am. ACAD. Pol. \& Soc. Scr. 63 (2009); see generally Martín Gubbins \& Carla López, Chile, in 622 Annals Am. ACAD. Pol. \& Soc. ScI. 68 (2009); see generally Ángel R. Oquendo, Upping the Ante: Collective Litigation in Latin America, 47 Colum. J. Transnat'u L. 248 (2009).

14. See Mark A. Behrens, Gregory L. Fowler \& Silvia Kim, Global Litigation Trends, 17 Mich. St. J. INT'L L. 166, 172-81 (2008-2009); Luiz Migliora et al., Trial and Error: Class Actions in Brazil and the US, and Global Trends, LaTin LaWYER, Sept. 2007, at 38, 39.

15. See Ángel R. Oquendo, supra note 13 , at 259 ("For instance, some tribunals south of the border have created, sua sponte and in the absence of any enabling legislation, a joint writ of protection.").

16. One example can be found in the now famous ruling T-025 of 2004 by the Colombian Constitutional Court, which ordered the aggregation of 109 individual actions and created a system for dealing with the status of many families displaced as a result of the guerrilla wars in that country. The Court established that several fundamental rights had been violated and took unprecedented action to remedy this. See Corte Constitucional [CC] [Constitutional Court], febrero 6, 2004, Sentencia T025/04 (Colom.). For an in-depth analysis of decision T-025 and its policy implications, see César Rodríguez Garavito \& Diana Rodríguez Franco, Cortes y Cambio Social: Como la Corte Constitucional transformó desplazamiento forzado EN Colombia, Centro de Estudios de Derecho, Justicia y Sociedad, Dejusticia (2010), available at http://www.rtfn-watch.org/uploads/media/Colombia_-_Cortes_y_cambio_ social.pdf (2010); Oscar Dueñas, Desplazamiento Interno Forzado: Un Estado de Cosas Inconstitucional que se agudiza: Effectos de la Sentencia T-024 de 2004 de la Corte Constitucional (Universidad del Rosario 2009); Ángel R. Oquendo, Latin American Law 242-58 (Foundation Press 1st ed. 2006). 
A small but forceful group of countries ${ }^{17}$ have gone further by adopting legislation that enables class actions and other forms of aggregate litigation. The new laws vary greatly by country, ranging from the inclusion of a few provisions in a given statute ${ }^{18}$ to the comprehensive overhaul of several laws ${ }^{19}$ or the passage of constitutional amendments that exalt the importance of advancing the collective protection of individual rights. ${ }^{20}$

This article explores the context in which the regulation of class actions is emerging in Latin America. To that end, this article describes the different forms of aggregate and group litigation that exist in that region, from the mechanisms traditionally included in the different codes of civil procedure and other legislation to the recently enacted vehicles for the protection of individual and collective rights.

Further, this article focuses on the differences and similarities in procedural rules and legal practices regarding the use of remedies against collective harms. This paper also explores the different incentives and obstacles created by the new statutes and delves into the question of how these laws might affect the development of collective litigation in the region.

The article is divided into four sections. Following this introduction, Section II offers an overview of the regulatory context of collective redress in Latin America. Section III focuses on the five jurisdictions that have enacted statutes regulating class actions and other forms of aggregate litigation and briefly describes some of the challenges faced by these newly enacted procedural vehicles. The conclusion is presented as Section IV.

A cautionary note regarding Latin America is in order. By treating the region as a unit, one runs the risk of oversimplifying a very complex reality that encompasses twenty different countries, each with its own official legal system, political institutions, and distinctive social and economic reality. ${ }^{21}$ Despite the fact that they belong to the same legal tradition and share similar legal institutions, ${ }^{22}$ no one could say, for example, that Venezuela and

17. As I will explain in Section III infra, these are Argentina, Brazil, Chile, Colombia, and Mexico.

18. See infra Section III, Chile.

19. See infra Section III, Mexico.

20. See infra Section III, Colombia and Brazil.

21. See Rogelio Pérez-Perdomo, Notes of a Social History of Latin American Law: The Relationship between Legal Practices and Principles, 52 Rev. Col. Aв. 1, 1 (P.R. 1991); see OQUeNDo, Latin AMERICAN LaW, supra note 16, at 3.

22. See generally John Henry Merryman \& Rogelio Pérez-Perdomo, The Civil 
Chile are the same, or that Guatemala and Paraguay could or should be treated equally.

Latin American countries also embody different social, economic and political realities that obviously affect how the law operates. ${ }^{23}$ The Argentine financial crisis of the late nineties, which prompted the filing of more than one hundred thousand writs of protection, ${ }^{24}$ and the Colombian humanitarian crisis of the early 2000s, which gave rise to hundreds of claims filed on behalf of tens of thousands of displaced people in different courts throughout the country, ${ }^{25}$ are just two examples of external factors that have prompted the legal machinery to react.

In both cases, the absence of specific legislation to deal with mass harms prompted lawyers and judges to come up with different ways to handle such an unprecedented number of claims in an efficient manner. Legal actors also had to craft solutions by maneuvering the law or by adapting its application to the specific circumstances at hand. ${ }^{26}$ These phenomena have naturally shaped how litigants strategize the use of legal tools in each country, and it has also had an impact on the policy debate about the implementation of procedural vehicles such as class actions. One could draw similar experiences from Brazil or Chile, for example, and notice how the responses would be unique to each place.

Notwithstanding their contrasting realities, Latin American jurisdictions also have many things in common. The first element that comes to mind is their former status as colonies of Spain and Portugal. ${ }^{27}$ In this regard, most Latin American countries not only

Law Tradition: An Introduction to the Legal Systems of Europe and Latin AMERICA 1 (Stanford University Press 3d ed. 2007).

23. See Lawrence M. Friedman \& Rogelio Pérez-Perdomo, Latin Legal Cultures in the Age of Globalization, in Legal Cultures in the Age of Globalization: Latin America and Latin Europe 1, 1 (Lawrence M. Friedman \& Rogelio Perez-Perdomo, eds., Stanford University Press 2003).

24. Osvaldo Alfredo Gozaíni, El derecho de amparo y la emergencia judicial (unpublished manuscript) (on file with Colegio Público de Abogados de la Capital Federal).

25. See generally César Rodríguez Garavito \& Diana Rodríguez Franco, Cortes y Cambio Soclal: Como la Corte Constitucional transformó desplazamiento forzado en Colombia: Effectos de la Sentencia T-024 de 2004 de la Corte Constitucional, Centro de Estudios de Derecho, Justicia y Sociedad, Dejusticia (2010), available $\alpha t$ http://www.rtfn-watch.org/uploads/media/Colombia__Cortes_y_cambio_social.pdf (2010); Oscar Dueñas, Desplazamiento Interno Forzado: Un Estado de Cosas Inconstitucional que se agudiza: EfFectos de la Sentencia T-024 de 2004 de la Corte Constitucional (Universidad del Rosario 2009).

26. See Garavito \& Franco, supra note 25 , at 79.

27. See Matthew C. Mirow, Latin American Law: A History of Private Law 
share a common history, a set of cultural traits including-with the notable exception of Brazil-language, but more importantly, the same sources of official law..$^{28}$

Even after the national independence processes that took place during the eighteenth century, the then newly-formed nations continued influencing each other's legal systems and have since maintained a certain level of convergence with respect to key legal institutions and practices. ${ }^{29}$ One example can be found in the approach given to codification, ${ }^{30}$ and more recently, to the inclusion of constitutional provisions referred to in third generation rights. ${ }^{31}$ One feature more akin to the discussion on collective litigation is the existence of remedies such as the constitutional writ of protection known as amparo, ${ }^{32}$ tutela, ${ }^{33}$ or mandato de segurança, ${ }^{34}$ which has been traditionally relied upon to offer redress against collective harms. ${ }^{35}$ Another common trait of Latin American jurisdictions is the ban on contingency-fee arrangements, which is still prevalent in national legal systems throughout the region, from Mexico to Argentina. ${ }^{36}$

Another shared feature of Latin American legal systems is the prohibition of punitive or exemplary damage awards, and the prevalence of the loser-pays (English) rule in civil litigation. ${ }^{37}$ Further, some of these aspects also help set Latin America apart from the United States, where contingency-fee arrangements and punitive damages not only exist but are widely accepted and have played a key role in the development of aggregate litigation.

These common traits and the corresponding challenges that come with them, coupled with the fact that the debate on the

and Institutions in Spanish America 12, 13 (University of Texas Press 2004); PérezPerdomo, supra note 21, at 1 .

28. See Angel Oquendo, Latin American Law, supra note 16, at vi-vii.

29. See Friedman \& Pérez-Perdomo, supra note 23; John Henry Merryman \& Rogelio Pérez-Perdomo, Two Legal Traditions, in The Civil Law Tradition 2-3 (3d ed. 2007).

30. See Merryman \& Pérez-Perdomo, supra note 22, at 27.

31. See Oquendo, supra note 13, at 254; see generally André Lapeyre, François de Tinguy, \& Karel Vasák, Les différentes categories des droits de l'homme [The Different Categories of the Rights of Man], in 1 Les Dimensions Universelles des Droits De L’Homme 297 (1990) (Belg.).

32. See, e.g., Constitución Política de los Estados Unidos Mexicanos [C.P.], art. 107, Diario Oficial de la Federación [DO], 30 de Diciembre de 1950 (Mex.); Art. 43, CONSTitución NACión [Const. NAC] (Arg.).

33. See Constitución Política de Colombia [C.P.] art. 86.

34. See Constituiç̃a Federal [C.F.] [Constitution], art. 5 (LXIX) (Braz.).

35. See Oquendo, supra note 13 , at 262.

36. See Gómez, supra note 2, at 296.

37. Id. at 297. 
adoption of class actions has gained prominence in different jurisdictions almost simultaneously, justify a common assessment of the region with respect to group litigation. In addition, by looking at different Latin American jurisdictions collectively, one can also compare and contrast the different approaches to group litigation and the legislative solutions given to common problems.

\section{From the traditional defense of Individual Rights TO THE CONSTITUTIONAL PROTECTION OF COLLECTIVE INTERESTS: JOINDER AND THE WRIT OF AMPARO}

As is the case for most countries that follow the civil-law tradition, Latin American procedural rules have historically focused almost exclusively on non-aggregate, individual litigation. By way of exception, specific provisions included in the different codes of civil procedure, ${ }^{38}$ and more recently in several constitutions ${ }^{39}$ and some special statutes, ${ }^{40}$ enable multiple parties to pursue their claims or defenses within a single litigation. ${ }^{41}$ The two traditional procedural vehicles that allow this are joinder and the writ of amparo.

Joinder (litisconsorcio) rules allow the consolidation of parties either because there are questions of law or fact common to those acting as plaintiffs (litisconsorcio activo) or defendants (litisconsorcio pasivo,${ }^{42}$ because the action has arisen out of the same transaction or series of transactions, or because the parties have asserted right to relief or defense jointly. ${ }^{43}$ Depending on how important the law deems the presence of certain litigants in the proceedings, Latin American codes of civil procedure also contain rules about permissive (litisconsorcio facultativo) $)^{44}$ and compul-

38. See, e.g., Código Procesal Civil [Cód. Proc. Civ.] [Code of Civil Procedure], art. 82 (Peru); Código Procesal Civil [Cód. Proc. Civ.] [Code of Civil Procedure], art. 582 (Parag.); Ada Pellegrini Grinover, Novas Tendências em materia de legitimaçao e coisa julgada nas ações coletivas. Relatório Geral-Civil Law, in Direito Processual Comparado, XIII World Congress of Procedural LaW (Ada Pellegrini Grinover \& Petr?nio Calmon eds., 2007) (Braz.).

39. See Oquendo, supra note 13 , at 262 n.38.

40. See Eurico Ferraresi, Ação Popular, Ação Civil Pública e Mandado de Segurança Coletivo: Instrumentos Processuais Coletivos 68- 89 (2009) (Braz.).

41. See Mirow, supra note 27, at 180.

42. See generally Maria Encarnación Davila Millán, Litisconsorcio Necesario: Concepto y Tratamiento Procesal 1 (1992).

43. Id.

44. See, e.g., Código de Procedimiento Civil [Cód. Proc. Civ.] [Civil Code of Procedurel, art. 107 (Costa Rica). This is similar to the "permissive joinder" 
sory joinder (litisconsorcio necesario). ${ }^{45}$

By enabling the consolidation of claims in the same litigation, joinder promotes efficiency and ensures uniformity of outcomes with respect to the parties; ${ }^{46}$ the claims are to be litigated before the same judge whose decision rendered on the merits will have res judicata effects with respect to all those involved and will preclude the parties from raising the same claims in a separate suit. ${ }^{47}$ Also, because joinder is generally allowed in any civil case, there are no limitations with respect to the type of remedies-injunctive relief or monetary damages-sought by the parties, thus making joinder a suitable solution in many cases. However, despite the inexistence of a cap with regard to how many parties are permitted to join in one action either as plaintiff or defendant, joinder is usually impracticable in cases involving mass-damage claims. ${ }^{48}$

The writ of amparo (mandato de segurança in Brazil $^{49}$ or acción de tutela in Colombia ${ }^{50}$ ) is a procedural remedy originally devised as a constitutional mechanism to protect citizens against the actions or omissions of public or private entities that have allegedly violated their fundamental rights. ${ }^{51}$ Amparo ${ }^{52}$ initially appeared in the 1841 Constitution of the Republic of Yucatán ${ }^{53}$ (currently a province of Mexico). The Mexican Constitution of 1857 broadened the scope of this remedy against judicial acts that allegedly violated individual constitutional rights. ${ }^{54}$ Further, the

established in Rule 20(a) of the Federal Rules of Civil Procedure. See FED. R. Crv. P. 20(a).

45. See, e.g., Cónigo de Procenimiento Civil [Cód. Proc. Civ.] [Civil Code of Procedure], art. 83 (Colom.).

46. Richard D. Freer, Rethinking Compulsory Joinder: A Proposal to Restructure Federal Rule 19, 60 N.Y.U. L. REv. 1061, 1061 (1985).

47. See Alan N. Polasky, Collateral Estoppel-Effects of Prior Litigation, 39 Iowa L. Rev. 217, 217-18 (1953-1954); Tobias Barrington Wolff, Preclusion in Class Action Litigation, 105 Colum. L. Rev. 717, 789 (2005).

48. Deborah R. Hensler, The Globalization of Class Actions: An Overview, in The Annals of Am. ACad. Pol. \& Soc. Sci. 1, 16 (2009).

49. See Constituiçāo Federal [C.F.] [Constitution], art. 5 (LXIX) (Braz.).

50. See Constitución Política de Colombia [C.P.], art. 86.

51. See Héctor Fix-Zamudio, El Amparo Mexicano como Instrumento Protector de los Derechos Humanos, in Ensayos sobre el Derecho de Amparo 254 (1993) (Mex.); Matthew C. Mirow, Marbury in Mexico: Judicial Review's Precocious Southern Migration, 35 Hastings Const. L.Q. 41, 64 (2006).

52. Mirow, supra note 51, at 83.

53. See Constituctón de la República de Yucatán [Cons. Yucatán], de 1841 (Mex.).

54. See Constitución Política de los Estados Unidos Mexicanos [C.P.], de 1857 (Dublan, Manuel and Lozano, José María, Legislación Mexicana o colección completa de las disposiciones legislativas expedidas desde la independencia de la República, edición oficial, Mexico, 1877, tomo VIII pp. 384-399) (Mex.). 
1917 Mexican Federal Constitution expanded the writ of amparo even more and shifted its focus from the protection of individual rights to include rights of social or collective nature. ${ }^{55}$

During the second half of the twentieth century, other Latin American countries adopted the writ of amparo. ${ }^{56}$ This remedy was generally regulated by way of constitutional provisions ${ }^{57}$ geared to facilitate access to justice and to widen the protection of individual and-during the most recent constitutional reform movement-collective rights. ${ }^{58}$

As Latin American constitutions shifted their interest to advance the promotion of social solidarity and third-generation rights $^{59}$ and assigned the state a more active role in the protection of the citizenry, amparo suits became increasingly popular. ${ }^{60}$ Moreover, the perceived judicial congestion and backlog of civil courts throughout the region made the filing of amparo suits very attractive. ${ }^{61}$

Amparo suits often involved the possibility of expedited pro-

55. See Constitución Política de los Estados Unidos Mexicanos [C.P.], art. 107, de 1917 (Mex.); Matthew C. Mirow, Case Law in Mexico 1861 to 1919: The Work of Ignacio Luis Vallarta, in 11 RAtio Decidendi 223, 227 (W. Hamilton Bryson \& Serge Dauchy, eds., 2006).

56. See generally Pedro Aberasturi et al., La Protección Constitucional del Ciudadano: Argentina, Brasil, Chsile, Colombia, Costa Rica y Venezuela (Ciedla 1999); Allan Brewer-Carías, El Derecho de Amparo en Venezuela, in Garantías Jurisdiccionales para la Defensa de los Derechos Humanos en Iberoamérica (1992).

57. See Constitutions of Art. 43, Constitución Nación [Const. Nac], (1994) (Arg.); Constitución Política de la República de Bolivia, art. 222 (1967); Constituiçăo Federal [C.F.] [Constitution]], art. 5 (1934) (Braz.); Constitución Politica de la República de Costa Rica art. 48 (1989); Constitución Politica de la República de El Salvador, art. 182 (1991); Constitución Politica de la República de Guatemala, art. 265 (1985); Constitución Politica de la República de Honduras, art. 183 (1982); Constitución Política de los Estados Unidos Mexicanos [C.P.], art. 107, (1917) (Mex.); Constitución Politica de la RePública de Nicaragua [CN.], art. 188 (1987); Constitución Politica de la República de Panama, art. 54 (1983); Constitución Politica de la República de Paraguay, art. 134 (1992); Constitución Politica de la República de Peru, art. 200 (1993), and; Constitución Politica de la República de Venezuela, art. 281 (1999).

58. Oquendo, supra note 13 , at 262-63.

59. Id. at $270-71$.

60. See generally Victor Arias Aroca, Amparo Constitucional: Uso y Abuso, Todo Sobre el Amparo Constitucional (Editorial Manta, 1st ed. 2001).

61. Ana Espinoza Díaz, Amparo Appeals: Problems Before, and After, the Reform, 2 INDRET (April 2010), http://papers.ssrn.com/sol3/papers.cfm?abstract_id=1639033; Enrique Gómez Santillán \& Lucía Echeverría Galeas, La Inseguridad Jurídica Generada por la Mala Práctica en el Amparo Constitucional (June 2003) (unpublished master's thesis located at Instituto de los Altos Estudios Nacionales), available at http://repositorio.iaen.edu.ec/bitstream/24000/228/1/LAEN-010-2003.pdf 
ceedings through specially appointed "constitutional" courts able to more swiftly enforce their rulings. The rise of amparo suits prompted the legislatures of several Latin American countries to enact special statutes to further develop this procedural vehicle, mainly with regard to its effects and scope. ${ }^{62}$

Even though, in general terms, the writ of amparo affords the same kind of protection throughout the region, national legal systems have adopted different variations of this remedy. For example, in some legal systems, amparo is basically implemented as a mechanism to protect individual citizens against unlawful imprisonment, similar to a writ of habeas corpus. ${ }^{63}$ In others, amparo can also be asserted against state or public agencies for a direct violation of a fundamental right, ${ }^{64}$ provided that such right is expressly mentioned by the constitution..$^{65} \mathrm{~A}$ broader and more recent variation of amparo allows it to be also used as a remedy against indirect violations of fundamental rights, that is, of those rights not expressly protected by the constitution but nonetheless regulated by statute. ${ }^{66}$

Further, in certain jurisdictions, amparo injunctions are allowed in cases of alleged constitutional violations attributed to private entities or individuals ${ }^{67}$ and may also be filed on behalf of absent individuals, members of socially-defined groups or catego-

62. See generally Allan-Randolph Brewer Carías \& Carlos Ayala Corao, la Ley Organica de Amparo sobre Derechos y Garantías Constitucionales (Editorial Jurídica Venezolana, 2d ed. 1988); Hêctor Fix-Zamudio \& Eduardo Ferrer Mac-Gregor, El Derecho de Amparo en el Mundo (Editorial Porrúa, 1st ed. 2006).

63. See generally Néstor Pedro Sagués, Amparo, Habeas Data y Habeas Corpus en la Reforma Constitudional (1994).

64. Constitución Política de la República del Ecuador [Constitution] June 5,1998 , art. 95 .

65. Some Latin American constitutions have recently included a mechanism specifically intended to protect the right to privacy and handling of personal information (habeas data), which-with the exception of Argentina-is treated separately from amparo. Compare Art. 43, Constitución NaCional [Const. Nac.] (Arg.); with Constituição Federal [C.F.] [Constitution] Oct. 5, 1988, art. 5 (Braz.); Constitución Politica de la República de Paraguay, art. 135 (1992); Constitución Política de la República del Perú 1993 [Constitution] art. 200 section 3 (1993); Constitución Política de la República del Ecuador [Constitution] Sept. 28, 2008, art. 95; Constitución de la República de Colombia [Constitution] July 4, 1991, art. 86; and Constitución de la República Bolivariana de Venezuela [Constitution] Dec. 15, 1999, art. 27.

66. See generally María de los Ángeles Eduwiges Chavira, Reflexiones sobre el Juicio de Amparo en materia civil, Directo e IndiRecto (Editorial Porrúa, 2005); Richard D. Baker, Judicial Review in Mexico: A Study of the Amparo Suit (University of Texas Press, 1st ed. 1971).

67. See generally José Ignacio Martínez Estay, Los particulares como sujetos 
ries of individuals situated in a similar position to the plaintiff (collective interests), and even on behalf of the general population (diffuse interests).

As a result, the decision rendered on the merits in these collective amparos (amparos colectivos) often has res judicata effects beyond the "representative" parties and precludes any future claims by anyone benefited from the decision. ${ }^{68}$ In many jurisdictions, collective amparos are the only form of representative litigation allowed. ${ }^{69}$

Despite their versatility, collective amparos have an important limitation. As these procedural vehicles are geared to protect against the violation of constitutional rights, and their main goal is to restore the status quo ex ante and not to compensate the victim in economic terms, amparo judgments are of purely injunctive nature. Amparo injunctions are limited to order the defendant to do, or to refrain from doing, certain acts and expressly foreclose the possibility of awarding monetary damages to the petitioner. ${ }^{70}$ Damages would have to be pursued in a separate trial as per the ordinary rules of civil procedure.

The Latin American protection of collective rights beyond the writ of amparo

The transition from dictatorship to democracy experienced by several Latin American countries during the decade of the eighties fostered the revival of key legal and political institutions and their role in the protection of individual and collective rights. This included the passage of important constitutional reforms, most of which adopted principles that expressly protected the collective and individual spheres of distinguishable social groups (intereses colectivos) and also included guarantees for the safeguard of broader interests, such as those related to the environment, public health and economic welfare (intereses difusos).

These constitutional reform processes also shifted the center of gravity from codes to constitutions. In addition, these reforms also expanded their scope from the first (civil and political) and second (social, economic and cultural) generation rights focused on the individual to those rights that put emphasis on the defense of

pasivos de los derechos fundamentales: La doctrina del efecto horizontal de los derechos, Numero Especial Revista Chilena de Derecho 59-64 (1998).

68. See Corte Suprema de Justicia de la Nacion [CSJN] [National Supreme Court of Justice], Feb. 24, 2009, "Halabi, Ernesto C. Poder Ejecutivo Nacional (P.E.N.) - Ley 25.873," dto. 1563/04 s/ amparo ley 16.986 (Arg.) [hereinafter Halabi].

69. Oquendo, supra note 13 , at 262-65.

70. See generally BRewer-CARÍAS \& CoRAo, supra note 62 . . 
collective interests, otherwise known as third generation rights. ${ }^{71}$ This trend helped motivate governments to pay more attention to policies dealing with consumer protection and to launch or support the expansion of public agencies and consumer advocate groups.

To this date, more than a dozen Latin American constitutions contain at least one provision that mentions consumer protection as an important policy. ${ }^{72}$ Such provisions, however, are often framed as general guidelines (normas programáticas) that call for further legislative action to develop the means through which individuals and socially identifiable groups are able to obtain compensation for harms.

An even greater number of countries have passed Consumer Protection Acts (CPAs) as part of broad strategies that have included the establishment of administrative agencies, ombudsmen and defense groups vested with duties that range from policymaking to education, training, and advocacy on behalf of consumers through administrative and judicial processes. ${ }^{73}$

Notwithstanding these important initiatives, Latin American countries are still far behind - as compared with other regions of

71. See generally Lapeyre, Tinguy andVasák, supra note 31 .

72. These are the Constitutions of the following countries: (1) Argentina, Constitución Nacional [Const. Nac.] Aug. 22, 1994, art. 42 (Arg.); (2) Brazil, Constituição Federal [C.F.] [Constitution] Oct. 5, 1988, art. 5 (Braz.); (3) Colombia, Constitución Política de Colombia [C.P.] July 4, 1991, art. 78; (4) Costa Rica, Constitutión Política De La Republica De Costa Rica [Constitution] Nov. 7, 1949, art. 46; (5) Ecuador, Constitución Política de la República del Ecuador [Constitution] Sept. 28, 2008, art. 92; (6) El Salvador, Constitución de LA República de El Salvador [Constitution] Dec. 20, 1983, art. 101; (7) Guatemala, Constitución Política de la República de Guatemala [Constitution] May 31, 1985, arts. 119, 130; (8) Honduras, Constitución Política de la República de Honduras [Constitution] May 4, 2005, arts. 331, 347; (9) Nicaragua, Constitución Politíca de la República de Nicaragua [CN.] Jan. 9, 1987, art. 105, La Gaceta, Diario Oficial [L.G.]; (10) Panama, Constitución Politíca de la República de Panama [Constitution] Oct. 11, 1972, art. 279; (11) Paraguay, República de Paraguay, Constitución Política de 1992 [Constitution] June 20, 1992, art. 72; (12) Peru, Constitución Política del Peru 1993 [Constitution] Dec. 31, 1993, art. 65; and (13) Venezuela, Constitución de la República Bolivariana de Venezuela [Constitution] Dec. 15, 1999, art. 117.

73. See, e.g., United Nations Conference on Trade and Development (UNCTAD), Strengthening Institutions and Capabilities in the area OF Competition and Consumer Protection Policies in Latin america: Cases of Bolivia, Costa Rica, El Salvador, Honduras, Guatemala, Nicaragua, and Peru, UNCTAD/DITC/CLP/2004/3 (United Nations 2005), available at http://unctad.org/en/ Does/ditcclp20043_en.pdf; see also Javier Lopez, Consumers Rights: Constitutional Consecration in Latin America (Derechos Del Consumidor: Consagración Constitucional En Latinoamérica) (2003), http://ssrn.com/abstract=1488127. 
the world-with respect to the implementation of effective vehicles for the protection against collective harms. Overall, consumer protection statutes have been conceived in very general terms. The powers granted to consumer protection agencies-even though ample in theory-are generally confined to the intervention in administrative or judicial proceedings that, when successful, only result in the imposition of small fines or other symbolic sanctions with little or no deterrent effect on the violators. ${ }^{74}$ One of the most dramatic shortcomings of the current scheme is the inability to effectively compensate victims and deter wrongdoers from recurring harmful conduct.

General procedural rules traditionally adopted by most Latin American national legal systems, such as the prohibition of contingency fee arrangements, the inexistence of punitive damages, and the prevalence of the loser-pays-all rule regarding lawyers' fees, are also credited with posing additional obstacles that impede the growth of consumer representative litigation in the region. ${ }^{75}$ But as shown in Section III of this paper, there has been change on that front.

\section{Like Migratory Birds}

The lack of effective remedies and the existence of several important shortcomings within Latin American jurisdictions, in conjunction with the perceived advantages of other legal systems, has fueled a migratory wave of claimants from Latin America to the United States ${ }^{76}$ where the use of civil litigation as a tool for regulating risk behavior and for compensating harms that affect large groups of citizens has achieved a high level of sophistication as a result of the confluence of certain economic, intellectual, procedural, and political factors. ${ }^{77}$ Consequently, Latin American citizens have viewed the possibility of pursuing their claims in United States courts as a panacea and have found in American class actions an appropriate vehicle to channel their claims. The general perception seems to be that the number of mass tort cases filed in United States courts by foreign plaintiffs is on the rise. ${ }^{78}$

74. See, e.g., Ley Federal de Protección al Consumidor [Federal Consumer Protection Actl Apr. 9, 2012, art. 125 et seq. (Mex.).

75. Gómez, supra note 2, at 296.

76. Id. at 300 .

77. Richard Nagareda, Mass Torts in a World of Settlement 1-6 (University of Chicago Press 2007).

78. Wurmnest, supra note 1 , at 205. 
Not all foreign cases, however, make it to American courts, and those that do are-arguably - subject to a stricter scrutiny than that faced in their own jurisdictions. Foreign cases are also screened and selected more carefully by American counsel to determine feasibility from both legal and financial viewpoints. American judges have also placed an additional barrier on foreign parties by refusing to allow claims when there is a risk that a foreign court will not give preclusive effect to a judgment rendered in the United States, thus allowing the plaintiff to successfully relitigate the same case in multiple fora. ${ }^{79}$ On the other hand, the existence of blocking or claw-back statutes in Latin America also poses an obstacle to those who consider bringing their claims in United States courts. ${ }^{80}$

While earlier empirical research showed that foreign plaintiffs tended to win a higher percentage of cases in United States federal courts than domestic litigants, ${ }^{81}$ pursuing litigation in the United States is not a stable long-term solution for Latin American plaintiffs. ${ }^{82}$ At the same time, an increasing number of consumer-advocacy groups, grass-roots organizations, government agencies, and actors throughout Latin America are currently lobbying for the regulation of class actions and similar procedural vehicles. ${ }^{83}$ As a result, proposals for convergence toward the American model of group litigation seem to be gaining popularity around the region. ${ }^{84}$

At the time of writing (September 2011), only a handful of Latin American countries-Argentina, Brazil, Colombia, Chile and Mexico-have adopted statutes providing for class actions or similar procedural mechanisms. While the predominant focus has been on consumer class actions, at least three countries-Colombia, Brazil and Mexico - have broadened the scope of these vehicles to other areas such as environmental and securities

79. Buschkin, supra note 4, at 1577.

80. Dahl, supra note 12 , at 27.

81. See Kevin M. Clermont \& Theodore Eisenberg, Xenophilia in American Courts, 109 HaRv. L. Rev. 1120, 1143 (1995).

82. See, e.g., Manuel A. Gómez, Like Migratory Birds: Latin American Claimants in U.S. Courts and the Ford-Firestone Rollover Litigation, 11 Sw. J.L. \& Trade Am. 281, 297 (2005).

83. See, e.g., Antonio Gidi, Class Actions in Brazil-A Model for Civil Law Countries, 51 Ам. J. Comp. L. 311, 329-30 (2003); Gustavo Mauriño et al., Las Acciones Colectivas (Lexis Nexis 2005) (Arg.).

84. Some, however, have warned against the adoption of a United States-style class action model appealing to a series of fundamental differences between the U.S. and Latin America. See, e.g., Gidi, supra note 83, at 330. 
litigation..$^{85}$

The regulatory framework of class actions in these countries differs in several important aspects. While in some jurisdictions, class actions are expressly backed by constitutional provisions and therefore regarded as an important state policy ${ }^{86}$ in others, class actions are simply judge-made and lack statutory regulation. ${ }^{87}$ There are also key differences regarding more technical issues such as standing, certification, early settlement, opt-in and optout procedures, litigation finance, fee-shifting rules, effect of the decision on the merits, and types of awards. The most salient aspects of each country are described in the following section.

\section{The Regulation of Representative Litigation in LATIN AMERICA}

\section{Colombia}

The protection of collective interests in Colombia can be traced back to the declaratory relief mechanism set forth among the traditional possessory actions in the country's 1887 Civil Code. ${ }^{88}$ Article 1005, for example, gives standing to municipal authorities and to any citizen seeking the demolition, repair, or compensation for damages in connection to a risk or actual harm posed by a building or construction..$^{89}$ The same provision entitles the plaintiff to obtain-as just compensation-one half of any fines imposed on the malfeasor as well as attorney fees for an amount no less than a tenth and no more than one third of the cost of the demolition, repair, or compensation. ${ }^{90}$ Similar provisions exist in other Latin American civil codes alongside traditional possessory actions (called interdictos). ${ }^{91}$

In spite of important procedural limitations, including the fact that article 1005 actions could only be pursued through individual litigation under the general rules of civil procedure; during

85. See infra Section III.

86. As it occurs in Brazil, Colombia and Mexico. See infra Section III.

87. This can be found in the case of Argentina. See infra Section III.

88. See generally Germán Sarmiento Palacio, Las Acciones Populares en el Derecho Colombiano (1988).

89. Código Civil [C.C.] art. 1476 (Colom.).

90. Id. Other popular actions included in the Civil Code to protect public goods are the ones set forth in articles 1006, 1007, 2358, 2359 and 2360.

91. See Jorge Adame Goddard, Evolución de los interdictos posesorios en México durante la primera mitad del siglo XIX, in Memoria del II Congreso de Historia del Derecho Mexicano 4 (1980); Pedro Villaroel Rion, La Posesión y los Interdictos en la Legislación Venezolana 3 (1988). 
the late 1980s, several Article 1005 cases were successfully litigated on behalf of large groups of consumers, thus paving the way for a greater reception of popular and group actions in Colombia. One of the most emblematic cases was the Alcalis litigation, which was pursued against a large corporation by Fundapúblico, a public interest litigation group. Fundapúblico based the claim, filed on behalf of the inhabitants of a town located near a riverbank, on the alleged pollution of the river by the defendant. ${ }^{92}$

A series of successive court victories and growing support from local and foreign donors strengthened Fundapúblico. Its members not only became successful lobbyists in a campaign to include a constitutional provision mentioning the protection of group rights, ${ }^{93}$ but also became successful lobbyists in the passage of a statute regulating group litigation in Colombia. ${ }^{94}$ Fundapúblico also became known for pursuing environmental claims on behalf of Colombian plaintiffs in United States courts, notably during the Dow Chemical litigation..$^{95}$

Beginning in 1982 with the passage of the Consumer Statute ${ }^{96}$ Colombia further developed the basis for regulating aggregate procedures geared to the defense of both private rights and public interests. The Environmental Protection Act of $1989^{97}$ and, later, the 1991 Constitution, ${ }^{98}$ declared the protection of collective rights a state policy and gave a boost to the prospect of regulating class actions in Colombia. ${ }^{99}$ In 1998, the Colombian Congress enacted the Popular and Group Actions Act (PGAC or Law 472), the main objective of which was to develop the principles set forth in Article 88 of the 1991 Constitution. ${ }^{100}$ As a result, PGAC created two different types of action, acción popular (popular action) and acción de grupo (group action). The former is a procedural vehicle geared to obtain injunctive or declaratory relief, instead of mone-

92. Mariana Sarmiento Aparicio, Biografia de German Sarmiento Palacio, in LAS Acciones Populares Privadas en el Derecho Colombiano 19 (2006).

93. Constitución Política de Colombia [C.P.] art. 86.

94. L. 472, augusto 5, 1998, [art. 1] Diario Oficial [D.O.] (Colom.).

95. Aparicio, supra note 92 , at 28.

96. L. 3466, diciembre 2, 1982, DiaRio Oficial [D.O.] (Colom.).

97. L. 9/38650, enero 11, 1989, Diario Oficial [D.O.] (Colom.).

98. Constitución Política de Colombia [C.P.] art. 88.

99. Id. ("The law will regulate popular actions for the protection of collective rights and interests related to the homeland, space, public safety and health, administrative morality, the environment, free economic competition, and others of a similar nature. It will also regulate the actions arising out of harm caused to a large number of individuals, without barring appropriate individual action. In some way, the law will also define cases of civil liability for harm caused to collective rights and interests.").

100. L. 472, agosto 5, 1998, [art. 1] Diario Oficlal [D.O.] (Colom.). 
tary damages, for violations deemed against the public interest. ${ }^{101}$ Group actions, on the other hand, were devised to offer a redress mechanism to a group, category or class of individuals uniformly situated with respect to an event or product that allegedly have caused them harm.

Popular actions may be filed in response to a broad range of situations, from the protection of a healthy environment to the preservation of the public decorum, ecologic balance, natural resources, public spaces, safety, and the guarantee of equal access to public services. ${ }^{102}$ Given the fact that popular actions are geared to protect the public interest and not the rights of a specific group, Article 13 PGAC enables any citizen or group of citizens to bring a popular action regardless of whether they have sustained any direct harm. ${ }^{103}$

As a way to facilitate access to judicial remedies even further, PGAC waived the requirement for plaintiffs to retain legal counsel, ${ }^{104}$ but provides that the Ombudsman's office (Defensoria del Pueblo $)^{105}$ shall be given notice of the proceedings so it can intervene on behalf of the public. ${ }^{106}$ Moreover, PGAC also gives standing to other government agencies either as parties proper ${ }^{107}$ or intervenors, ${ }^{108}$ including the Attorney General, district and municipal officials, and non-governmental organizations. ${ }^{109}$

Another important incentive offered to popular action plaintiffs is the possibility of requesting a waiver of court fees and other expenses connected to the proceedings. ${ }^{110}$ Plaintiffs are also exempted from the general fee-shifting rule, unless their claims are deemed frivolous or found to be filed in bad faith. ${ }^{111}$ Moreover, indigent parties can request that litigation be financed by the Fund for the Defense of Collective Rights and Interests (FDCR) established under Article 71, c, d PGAC. ${ }^{112}$ In such case, the

101. Id. art. 2; see Corte Constitucional [C.C.] [Constitutional Court], junio 8, 2004, Sentencia C-225/04 (Colom.); see also Corte Constitucional [C.C.] [Constitutional Court], abril 14, 1999, Sentencia C-215/99 (Colom.).

102. L. 472, agosto 5, 1998, [arts. 2, 4] Diario Ofictal [D.O.] (Colom.).

103. Id. arts. 12,13 .

104. Id. art. 13.

105. Constitución Política de Colombia [C.P.] art. 282.

106. L. 472, agosto 5, 1998, [art. 13] Diario Oficial [D.O.] (Colom.).

107. Id. art. 12 .

108. Id. art. 24.

109. Id. art. 13.

110. Id. art. 19.

111. L. 472, agosto 5, 1998, [art. 38] Diario Oficial [D.O.] (Colom.).

112. Id. art. $71(\mathrm{c}),(\mathrm{d})$. 
Ombudsman's office is given discretion to determine how much assistance can be offered. ${ }^{113}$ Conversely, ten percent of any award monies obtained in cases litigated with financial assistance from the FDCR shall be paid back to contribute to its capital. ${ }^{114}$ Even though Articles 39 and 40 of the PGAC originally conceived a monetary incentive under which prevailing plaintiffs were entitled to a success fee, a special statute abrogated both provisions in $2010 . .^{115}$

Given their scope, popular actions are subject to the exclusive jurisdiction of contentious administrative courts. ${ }^{116}$ Judges are vested with ample powers to issue precautionary measures, ${ }^{117}$ promote an early settlement, ${ }^{118}$ and order the production of ample evidentiary means. ${ }^{119}$ Finally, the decision rendered on the merits will have general effects (erga omnes). ${ }^{120}$

As mentioned earlier, the second type of procedural vehicle included in PGAC is the group action. ${ }^{21} \mathrm{~A}$ representative acting on behalf of a class may commence group actions. ${ }^{122} \mathrm{~A}$ class is defined by the existence of uniform conditions with respect to an event alleged to have inflicted harm on each and all of its members. ${ }^{123}$ Unlike popular actions, group actions are expressly intended to seek monetary compensation for individual damages suffered by class members. ${ }^{124}$

PGAC does not require the representative party claims to be typical of the rest of the class, but simply requires that the cause of the alleged harm is common to all class members and that the

113. Id. art. 73.

114. Id. art. $70(\mathrm{~g})$.

115. L. 1425, diciembre 29, 2010, [art. 1] Diario Oficial [D.O.] (Colom.). The incentives ranged between ten and 150 times the minimum wage, or fifteen percent of whatever monies were recovered in popular actions involving corruption charges. See L. 472, agosto 5, 1998, [art. 39, 40] Diario Oficial [D.O.] (Colom.).

116. L. 472, agosto 5, 1998, [art. 15] Diario Oficial [D.O.] (Colom.).

117. Id. arts. $17,25$.

118. Id. art. 27.

119. $I d$. art. 28.

120. Id. art. 35. However, on August 14, 2007, the Colombian Constitutional Court created an exception to the res judicata effect of the decision on the merits, if new and "transcendental" evidence is uncovered after the dismissal of a popular action. See Corte Constitucional [C.C.] [Constitutional Court], agosto 14, 2007, Sentencia C-622/ 07, publication name [publication abbreviation] (publication volume and/or number), page number (Colom.).

121. L. 472, agosto 6, 1998, [art. 46] Diario oficial (D.O.) (Colom.).

122. Id. art. 48.

123. Id. art. 46.

124. $I d$. 
class is comprised of at least twenty people. ${ }^{125}$ As in the case of popular actions, the Ombudsman, district and municipal officials each have standing to intervene on behalf of parties lacking representation. ${ }^{126}$

In addition, PGAC requires that the Ombudsman be notified of the filing of every new group action so she can ponder whether to intervene. ${ }^{127}$ The Ombudsman is also assigned the role of an early settlement facilitator ${ }^{128}$ which is obviously problematic for it seems to create a conflict of interest between the ombudsman as defender of the consumer and her role as mediator between the parties. ${ }^{129}$

Depending on whether the action is instituted against a public agency or private actors performing a public role, or simply against private parties, jurisdiction over group actions will fall either to the contentious administrative courts or the ordinary civil courts. ${ }^{130}$ With respect to class certification, the only two factors analyzed by the court to decide whether a claim should proceed as a group action are whether the alleged harm by all class members arose out of a common cause, ${ }^{131}$ and whether the twoyear statute of limitation has expired. ${ }^{132}$

Once the class is certified, the court shall direct notice to class members so they can opt-in and be treated as original parties, given that they join before the start of the evidentiary phase. ${ }^{133}$ Class members who did not participate in the proceedings may still opt-in within twenty days of the final ruling on the merits, but may not invoke exemplary damages or partake in any fee awards. ${ }^{134}$ Conversely, PGAC also provides class members with an

125. Id. On February 13, 2008, the Colombian Constitutional Court clarified that the twenty-person threshold does not refer to the number of representative plaintiffs, but rather, it refers to an identifiable group of individuals that form the class. See Corte Constitucional [C.C.] [Constitutional Court], febrero 13, 2008, Sentencia C-116/ 08.

126. L. 472, agosto 5, 1998, [art. 48] Diario Oficial (D.O) (Colom.).

127. Id. art. 53.

128. Id. art. 61.

129. While it is true that article 61 indicates that when the Ombudsman has acted as plaintiff and the mediator function will be performed by a representative of the Attorney General, that still does not guarantee any kind of neutrality because the Ombudsman's general duty would still be to protect the interests of consumers and ordinary citizens. $I d$. art. 61.

130. Id. at art. 50.

131. Id. at art. 3.

132. Id. at art. 47.

133. $I d$. at art. 53.

134. Id. at art. 55. The constitutional court abrogated the requirement that the 
opportunity to opt-out within five days following the term established to effect service of process. ${ }^{135}$

Unlike popular actions, Colombian group actions require plaintiffs to be represented by legal counsel, ${ }^{136}$ and the statute also provides for the formation of a plaintiff steering committee (PSC) led by the counsel that represents the largest number of parties. ${ }^{137}$ Lead counsel shall be appointed by the judge ${ }^{138}$ and is entitled to a fee equal to ten percent of the total monies awarded to any absent parties. ${ }^{139}$ The statute also provides that a settlement hearing shall be held immediately after the opt-out phase. If no agreement is reached, the proceedings shall continue until a final decision is reached on the merits. ${ }^{140}$ The decision will have res judicata effects for those class members who did not opt-out. ${ }^{141}$ Finally, the allocation of individual awards established by the final decision shall be administered by the FDCR, which, as explained earlier, is under the supervision of the Ombudsman's office. ${ }^{142}$

In addition to regulating the procedural aspects of group and popular actions, PGAC established a public registry of popular and group actions to be managed by the Ombudsman's office. ${ }^{143}$ The statute also charged the government with the duty to set up educational programs intended to raise awareness on the protection of collective rights, ${ }^{144}$ and also to facilitate the establishment of civil society organizations for the defense of collective rights. ${ }^{145}$

\section{Brazil}

The enactment of the lei da ação civil publica (LACP) in $1985^{146}$ and the código de defesa do consumidor of 1990 (CDC) $)^{147}$ placed Brazil at the forefront of the movement to promote con-

statute of limitations had not lapsed with respect to these class members. See Corte Constitucional [C.C.] [Constitutional Court] abril 10, 2009, Decision C-241-09.

135. L. 472 agosto 5, 1998, [art. 56] Diario Oficial (D.O.) (Colom.).

136. Id. at art. 49 .

137. Id.

138. Id.

139. Id. at art. 65-66.

140. Id. at art. 61.

141. L. 472 agosto 5, 1998, [art. 66] Diario Oficial (D.O.) (Colom.).

142. Id. at art. 72 .

143. Id. at art. 80 .

144. Id. at art. 85.

145. Id. at art. 81.

146. Lei No. 7.347, de 2424 de Julho de 1985 (Braz.), available at http://www. planalto.gov.br/ccivil_03/Leis/L7347orig.htm.

147. Lei No. 8.078, de 11 de Setembro de 1990 (Braz.), available at http://www. planalto.gov.br/ccivil_03/leis/L8078.htm. 
sumer class actions in Latin America ${ }^{148}$ Consistent with the principles outlined in article 5 of the 1988 Brazilian constitution, which deemed the protection of consumer rights a duty of the state, ${ }^{149}$ LACP and CDC created a procedural vehicle that further developed representative litigation in that country.

Prior to the enactment of these two statutes, however, Brazil had already recognized the importance of protecting collective rights and had created limited procedural remedies that sought the annulment of public acts deemed to go against basic constitutional principles. The Constitution of 1934, for example, created a procedure (actio popularis) to challenge statutory acts deemed to affect the public interest. ${ }^{150}$

In 1965, a special statute called lei da ação popular (LAP) was passed as a way to expand the remedies against acts affecting government entities. ${ }^{151}$ One of LAP's main contributions was to loosen the limitations with respect to standing and to enable any citizen to bring a public action without having to meet any special qualification. After all, LAP's main goal was to protect the interest of the general population and not the rights of individuals or specific groups. LAP, however, did not address the issue of claim aggregation.

Decades later, the passage of both LACP and CDC made possible the collection of large numbers of small individual claims against private actors. Cases arising out of the same factual or legal circumstances common to a group, class or category of consumers were now candidates for aggregation. ${ }^{152}$ One important limitation, however, was that these procedures were confined only to claims related to the protection of the environment, consumer rights, and rights related to artistic, aesthetic and historic values. ${ }^{153}$

148. See generally Beatriz Londoño Toro, Análisis de las estadísticas sobre acciones populares $y$ derechos colectivos, 29 Revista Tutela, Acciones Populares y DE Cumplimiento 1211, 1211 (2002); see generally Ada Pellegrini Grinover, Hacia Un Sistema Iberoamericano de Tutela de Intereses Transindividuales, in LA TuTELA DE los Derechos Difusos, Colectivos e Individuales Homogéneos (2004); Grinover, supra note 13 , at 63 .

149. Constituição Federal [C.F.] [Constitution] art. 5 (Braz.).

150. Constituição da República dos Estados Unidos do Brasil, de 16 de Julho de 1934 (Braz.), available at http://www.planalto.gov.br/ccivil_03/constituicao/ constitui\% C3\%A7ao34.htm.

151. Lei No. 4.717, de 29 de Junio de 1965, (Braz.), available at http://www. planalto.gov.br/ccivil_03/leis/L4717.htm; see also Gidi, supra note 83 at 326 n. 26; Keith S. Rosenn, Civil Procedure in Brazil, 34 Aм. J. Coмp. L. 487, 517 (1986).

152. Lei No. 8.078, de 11 de Setembro de 1990, art. 81 (Braz.).

153. See Rosenn, supra note 151 , at 522. 
With respect to the type of rights that warrant collective protection, CDC distinguishes between diffuse, collective and individual-homogeneous rights. ${ }^{154}$ The first category is comprised of "trans-individual and indivisible rights" that belong to an undetermined group of individuals not necessarily connected with each other except for the specific factual event that gave rise to the litigation, such as an environmental disaster. Diffuse rights usually refer to the preservation of the public good, as opposed to individual or group interests. ${ }^{155}$ Collective rights are "trans-individual and indivisible" but are specifically tied to a group, category or class determined by common elements of law or a pre-existing legal relationship. ${ }^{156}$ Lastly, individual-homogeneous rights are subjective rights but of common origin or cause. The common origin of these rights is precisely what makes the aggregation of numerous claims for judicial adjudication possible.

The openness of CDC in allowing different categories of right holders to bring class action suits appears to be in contrast with the rather restrictive rules on standing, which only allow suits filed by the Public Prosecutor (Ministério Público), states, municipalities, the Federal District, and consumer associations that comply with a number of prerequisites. These prerequisites include being established for at least one year prior to the filing of the suit. ${ }^{157}$ In any case, even if the Public Prosecutor does not appear as plaintiff, CDC requires that she be still notified of the proceedings ${ }^{158}$ as a way to ensure that absent parties are adequately represented..$^{159}$

CDC also enabled the filing of claims against multiple defendants by allowing the plaintiff to pierce the corporate veil of different entities and consolidate claims against them in a single suit. ${ }^{160}$ In order to enable potential claimants to join the litigation as parties, CDC also requires that, at least in the case of damage class actions, ${ }^{161}$ the notice requirement be fulfilled with publication in an official paper. ${ }^{162}$ The same provision authorizes consumer protection agencies to divulge the existence of the class action

154. Lei No. 8.078, de 11 de Setembro de 1990, art. 81 (Braz.).

155. See Gidi, supra note 83 , at 350,355 .

156. $I d$. at 356 .

157. Lei No. 8.078, de 11 de Setembro de 1990, art. 82(B) (Braz.).

158. Id. at art. 92 .

159. See Gidi, supra note 83 , at 339.

160. Lei No. 8.078, de 11 de Setembro de 1990, art. 28 (Braz.).

161. See Gidi, supra note 83 , at 342 .

162. Lei No. 8.078, de 11 de Setembro de 1990, art. 94 (Braz.). 
through other media outlets, in case they deem it adequate. ${ }^{163}$

Naturally, one of the most important effects of the procedural vehicle devised by CDC is the expansion of the res judicata effects of the decision rendered during the declaratory phase to the general population (erga omnes) or to any potential members of the group, class, or category of plaintiff (ultra partes). ${ }^{164}$ As a result, no new suit arising out of the same claims subject to the class action litigation can be brought again before a court. ${ }^{165}$ Interestingly, Article 103 of the CDC also contains language that enables individual class members to pursue separate actions should the collective proceedings prove unsuccessful. ${ }^{166}$ Interestingly, Article 103 of the CDC also contains language that enables individual class members to pursue separate actions should the collective proceedings prove unsuccessful. ${ }^{167}$

The Brazilian regulatory scheme has been perceived as including a series of innovative features. ${ }^{168}$ These include shifting the burden of proof to the defendant, adopting a strict liability rule that relieves the plaintiff from having to establish the defendant's culpability, ${ }^{169}$ and exempting the plaintiff from paying court fees and other related expenses. ${ }^{170}$ Nevertheless, as a practical matter these perceived incentives have neither translated into a surge in the filing of class actions nor into a large number of victories for plaintiffs. Rather, the contrary is what seems to have happened.

Take, for example, the class action lawsuits filed in Brazilian courts against tobacco manufacturers. Tobacco suits are by far the largest in terms of scope, alleged damages, remedies sought, and cost. Out of the ten collective cases litigated in Brazil since 1995, plaintiffs have not yet prevailed in a single one. The first of these cases was a class action lawsuit brought in the courts of São Paulo

163. Id.

164. Lei No. 8.078, de 11 de Setembro de 1990, art. 103 (Braz.).

165. In Brazil, as in most countries following the civil law tradition, the res judicata effects only apply to claims and do not apply to issues as they occur in the United States, which allows issue preclusion or collateral estoppel. See Gidi, supra note 83, at 385 .

166. Lei No. 8.078, supra note 147 , at art. 103; see also Gidi, supra note 83 , at 389.

167. See CDC at art. 103; see also Gidi, supra note 83 , at 39 .

168. See, e.g., Gidi, supra note 83 , at 339.

169. See CDC at art. 12 ("National or foreign manufacturers, producers, constructors, and importers are liable, regardless of the existence of culpability, for the redress of damages caused to consumers by defects from design, manufacture, construction, assembly, formula, handling, presentation or packaging of products, as well as for the improper or incomplete information about their use and risks.").

170. Id. at art. 87. 
by the Association for the Defense of the Health of Smokers (ADESF or Associação de Defesa da Saúde do Fumante) against Souza Cruz-the subsidiary of British American Tobacco-and Philip Morris Brazil. ${ }^{171}$ ADESF filed a suit on behalf of all smoking consumers who, according to the complaint, had been deceived by the defendants' misleading and abusive advertising practices. ${ }^{172}$ Among other requests, plaintiffs asked the court to order defendants to pay each Brazilian smoker a certain amount per year they had used cigarettes.

In 2004, the trial court sided with ADESF and issued an unprecedented ruling ordering defendants to pay $\mathrm{R} \$ 30$ billion $^{173}$ in damages to all Brazilian smokers $\left(R \$ 1,000^{174}\right.$ per person per year she had smoked). ${ }^{175}$ In 2008 , this ruling was reversed by the Seventh Civil Chamber of the Court of Appeals for the State of São Paulo. ${ }^{176}$ The Court of Appeals, which has consistently rejected this type of claim, vacated the award on grounds that the lower court had violated the defendants' due process by not allowing them to produce expert evidence during the trial. ${ }^{177}$ The case was remanded to the trial court for production of new evidence and a new decision on the merits. ${ }^{178}$ After being fully litigated once more, the case was finally dismissed on May 27, $2011 .{ }^{179}$ This decision was one more in a string of court rulings handed down by at least fifteen Brazilian state courts, ${ }^{180}$ as well as the Superior Court of Justice, ${ }^{181}$ denying claims filed against

171. See D.J.S.P., Processo no. 583.00.1995.523167-5, Associação de Defesa da Saúde do Fumante (ADESF) v. Souza Cruz S/A/ e Philip Morris Marketing S/A, 0704-2004 (Braz.) (on file with author).

172. Id.

173. Approximately, US $\$ 19.2$ billion as of July 2,2011 .

174. Approximately, US $\$ 642$ as of July $2,2011$.

175. See T.J.S.P., Processo no. 583.00.1995.523167-5, Associação de Defesa da Saúde do Fumante (ADESF) v. Souza Cruz S/A/ e Philip Morris Marketing S/A, 07-042004, 5 (Braz.) (on file with author).

176. See T.J.S.P., Apelaçao Cível com Revisão no. 479.713-4/8-00, Philip Morris Brasil, S.A. v. Associação de Defesa da Saúde do Fumante (ADESF), 12-11-2008 (Braz.).

177. Id.

178. Id.

179. See T.J.S.P., Processo no. 583.00.1995.523167-5, Associação de Defesa da Saúde do Fumante (ADESF) v. Souza Cruz S/A e Philip Morris Marketing S/A, 16-052011 (Braz.).

180. Brazilian Court Rejects Main Class Action Filed Against Cigarette Manufacturers, PR NewswiRe (May 27, 2011), http://www.prnewswire.com/newsreleases/brazilian-court-rejects-main-class-action-filed-against-cigarettemanufacturers-122716493.html.

181. Id. 
tobacco manufacturers. ${ }^{182}$

Despite the setbacks suffered by tobacco plaintiffs whose claims have been consistently dismissed, other consumers have had better luck in obtaining favorable outcomes, or at least in pressing the courts to devise deterrents traditionally absent in Latin America-such as exemplary damages. Brazilian judges, as well as their other Latin American counterparts, have traditionally rejected the possibility of awarding damages that go beyond the actual compensation for an actual harm and have often considered exemplary or punitive damages to go against public policy. Notwithstanding, increased pressure from consumer advocacy groups coupled with an inadequate administrative sanctioning regime, have pressed civil judges to come up with other deterrents that are more effective. ${ }^{183}$

One solution found by Brazilian courts is to award moral damages in lieu of punitive damages. ${ }^{184}$ Moral damages are allowed by most Latin American civil code countries as a form of compensation to those who have suffered mental anguish, degraded reputation, emotional injury, or social humiliation. ${ }^{185}$ Moral damages are not punitive in nature, but judges have a significant degree of discretion in determining the amount awarded. ${ }^{186}$ In order to be entitled to moral damages, the plaintiff needs only to prove the defendant's breach of duty (not the actual harm). In the case of economic damages, on the other hand, the victim also needs to prove and quantify the extent of the actual harm, which is more difficult.

Because of the discretion vested in the judges to calculate the amount of moral damages and the relative ease with which plaintiffs can assert them in court, some have found moral damages to be a second-best solution. In a 2008 case involving an individual

182. Id.

183. See, e.g. T.J.S.P., Apelaçao Cível com Revisão no. 479.713-4/8-00, Philip Morris Brasil, S.A. v. Associação de Defesa da Saúde do Fumante (ADESF), Dec. 11, 2008 (Braz.) (on file with author).

184. Id.

185. See Jorge A. Vargas, Moral Damages Under the Civil Law of Mexico. Are These Damages Equivalent to Punitive Damages?, 35 U. Miami Inter-Am. L. Rev. 183, 248 (2004); Edith Friedler, Moral Damages in Mexican Law: A Comparative Approach, 8 Loy. L.A. InT'L \& Comp. L. Rev. 235, 248 (1986); Saul Litvinoff, Moral Damages, 38 LA. L. REv. 1, 1 (1977).

186. See generally Jorge A. Vargas, Moral Damages Under the Civil Law of Mexico. Are These Damages Equivalent to Punitive Damages?, 35 U. Miami Inter-Am. L. Rev. 183, 208 (2004); Edith Friedler, Moral Damages in Mexican Law: A Comparative Approach, 8 Loy. L.A. InT'L \& CoMP. L. REv. 235 (1986); Saul Litvinoff, Moral Damages, 38 LA. L. REv. 1 (1977). 
consumer claim filed against a telephone company, the Sixth Civil Chamber of the Court of Appeals for the Mato Grosso State did exactly that. The plaintiff's main allegation was that he was mistakenly included on a list of delinquent debtors, which resulted in significant damage to his credit score and relationships with other providers. The court sided with the plaintiff and awarded him $\mathrm{R} \$$ 41,500 in compensatory damages.

In addition, as a way to "deter (the agent) from incurring in the same conduct again," 187 the court also awarded the plaintiff $\mathrm{R} \$$ 9 million in moral damages and expressly acknowledged "the punitive character of the award." 188 The court put particular emphasis on the fact that, in addition to compensating the victim for his suffering, such a high award would also "intimidate the defendant, and deter him from incurring again in a similar harmful conduct." 189

Proponents of consumer legislation reform and class actions in Latin America have advocated for the adoption of statutes providing for punitive damages, with very little success to date. At the time of writing, Argentina seems to be the only jurisdiction that allows punitive damages, but those punitive damages are confined to a specific type of dispute. ${ }^{190}$

\section{Argentina}

The possibility of awarding punitive damages or multas civiles (civil fines) ${ }^{191}$ is one of the most salient innovations of Argentina's 2008 amendment to the Ley de Defensa del Consumidor (LDC). LDC extends this form of judicial deterrent to both contractual and non-contractual disputes. The statute also gives ample discretion to the judge in calculating the specific amount of punitive awards, the only limit being that it should not exceed \$AR 5 million. ${ }^{192}$

More generally, and similar to what occurs in Colombia ${ }^{193}$ and Brazil, ${ }^{194}$ LDC gives standing to consumer associations, municipal

187. See T.J.M.T., Ap. Civ. No. 86538/2008, Manoel Goncalo de Alcantara v. Telemat Cellular S.A., 17-09-2008, 1 (Braz.).

188. Id.

189. Id.

190. Law No. 26361, Mar. 12, 2008, B.O. 31378, art. 25 (Arg.) [hereinafter LDC $2008]$

191. Id.

192. Id. at art. 25, art. 21(b).

193. See supra Colombia in this section.

194. See supra Brazil in this section. 
agencies, the ombudsman, and the Ministerio Público (Public Prosecutor, hereinafter "PP") to bring judicial actions on behalf of consumers whose rights have allegedly been violated. ${ }^{195}$ While LDC mentions the possibility of both individual and collective actions, ${ }^{196}$ the regulation of the latter is confined to two provisions. The first provision simply provides that consumer associations are required to apply for court approval to join any collective proceedings. ${ }^{197}$

Article 27 of the LDC, the second provision referring to collective litigation, is more comprehensive. It regulates several important aspects of collective litigation, ranging from the scope of settlement and opt-out rules to the effects of the final decision on the merits and the disbursement of award funds. ${ }^{198} \mathrm{LDC}$ expressly encourages the early settlement of consumer claims and subjects them to judicial approval. ${ }^{199}$ Should a proposed settlement be approved, the LDC provides that class members should be afforded an opportunity to opt-out. ${ }^{200}$ The statute, however, falls short of establishing any concrete mechanism by which class members are allowed to exercise this right. ${ }^{201}$ The specific opt-out procedure is hence left entirely to the judge's discretion with no other guidance than what the parties might propose. In any event, a final settlement agreement or judicial decision on the merits shall have res judicata effects upon the parties and all those similarly situated, with the obvious exception of those class members who opted out. ${ }^{202}$

Article 27 of the LDC also gives judges ample discretion in devising a system for the disbursement of settlement monies, including the formation of sub-classes or sub-categories of plaintiffs for more efficient management of settlements. ${ }^{203}$ Judges are also given the role of settlement fund managers and are granted authority to allow individual claimants to continue pursuing their claims separately whenever the settlement agreement only includes compensation for collective harms and not individual remedies. ${ }^{204}$

195. LDC 2008 at art. 24.

196. Id.

197. Id.

198. Id. at art. 27.

199. Id.

200. Id

201. Id.

202. Id.

203. Id.

204. Id 
With respect to the $\mathrm{PP}$, given her role as guarantor of legality and public order, her intervention is deemed compulsory, and she shall remain a party even if the plaintiff decides to withdraw her claim. ${ }^{205}$ Furthermore, the PP is also allowed to object or comment on any proposed settlement submitted to the judge for approval, unless the $\mathrm{PP}$ is already intervening as a party representative, in which case, only the judge's opinion is necessary. ${ }^{206}$

Consumer associations, on the other hand, require judicial authorization to intervene on behalf of individual or collective plaintiffs. ${ }^{207}$ Moreover, consumer associations are also subject to a series of prerequisites to operate. ${ }^{208}$ They are expected to remain completely independent ${ }^{209}$ and may only perform activities geared toward defending, informing and educating consumers. Consumer associations are also barred from engaging in political activism ${ }^{210}$ and cannot receive contributions from private, public, domestic or foreign companies. ${ }^{211}$ Given these significant limitations, funding is obviously a problem for Argentine consumer associations, as they depend almost exclusively on government support to function, and the public resources set aside for them are generally scarce.$^{212}$ In addition, one could also argue that consumer associations' dependence on public resources hinders their autonomy.

Notwithstanding the aforementioned obstacles, plaintiffs in consumer cases, collective or individual, regardless of their socioeconomic status or need, are automatically granted the benefit of litigating in forma pauperis (IFP) and are therefore exempted from court costs as well as witness and expert fees. ${ }^{213}$ Moreover, the IFP benefit also extends to attorney's fees. ${ }^{214}$ Defendants, on the other hand, have to bear their own court costs and attorney fees and also the prevailing party's attorney fees. This is yet another feature that makes Argentine consumer litigation highrisk for defendants and significantly inexpensive and low-risk for plaintiffs. Even though the rationale behind the IFP rule has been

205. Id. at art. 24.

206. $I d$. at art. 27.

207. Id. at art. 28, 58; Law No. 24240 , Oct. 15,1993 , [LIII-D] A.D.L.A. 4125 , art. 58

(Arg.) [hereinafter LDC 1993].

208. LDC 1993, supra note 207, at art. 56, 57 .

209. Id. at art. $57(\mathrm{~b})$.

210. Id. at art. 57(a).

211. Id. at art. 57(c).

212. See Resolución 105/2005, June 30, 2005, B.O. 30.685 (Arg.), available at http:// www.diputados-catamarca.gov.ar/ley/BO2005/BO300605.PDF.

213. LDC 2008 at art. 26, 28.

214. Id. 
to facilitate consumer access to the court system, it has also been criticized for encouraging abusive filing of claims and creating a significant power imbalance between the parties. ${ }^{215}$

In addition to LDC, several provincial statutes ${ }^{216}$ and appellate court decisions ${ }^{217}$ have opened the door to collective litigation in Argentina. Since at least 2002, different class action bills have been lingering in the Argentine Congress with no clear indication of when or if they will be passed anytime soon. ${ }^{218}$ Some older statutes, such as the Ley 23551 de Asociaciones Sindicales (Unions Act) $)^{219}$ and the Ley 25675 General del Ambiente (General Environmental Act), ${ }^{220}$ have enabled different actors such as unions, ${ }^{221}$ the Ombudsman and ordinary citizens, ${ }^{222}$ to represent collective rights in court.

The strongest endorsement to class actions, however, has come from the Argentine Supreme Court (CSJN) and its Halabi decision, handed down on February 24, 2009. ${ }^{223}$ The case involved a collective amparo suit filed by attorney Ernesto Halabi whereby he challenged the constitutionality of what the Argentine media touted the "Ley Espia" (Spy Law), ${ }^{224}$ a statute that authorized the wiretapping of all telephone and Internet communications. Acting in his own name and on behalf of all users of telecommunication services in Argentina, Halabi sought to repeal the Spy Law, argu-

215. See Hector A. Mairal, Collective and Class Actions in Argentina, National Report, The Globalization of Class Actions Conference Proceedings 23 (Dec. 2007), http://globalclassactions.stanford.edu/content/collective-and-class-actions-argentina.

216. Accord Law No. 11723 y decr. 4371/1995, Buenos Aires, Dec. 22, 1995, B.O. 2212-95 (Arg.), available at http://www.opds.gba.gov.ar/index.php/leyes/ver/64 [hereinafter Ley 11723]; Law No. 6944 directo reglamentario 2260/01, Mendoza, Nov. 6, 2001, B.O. 29-11-01 (Arg.) [hereinafter CPC Tucumán] (Arg.).

217. Mairal, supra note 215, at 9-10.

218. See id. at 25 . The first bill was submitted in 2002 by congressman Bauzá. Id. In 2005 , two bills were submitted, one by congressman Batuzzi, and the other one by representatives Camaño y Urtubey. Id. Congressman Urtubey presented again another bill in 2007. Id. In 2009, two more similar bills were submitted again to the Argentine Congress. Id. None made it past deliberations. Id.; See also Anthony Andrade, William Crampton \& Diego Gandolfo, Shook, Hardy \& Bacon, LLP, International Class Action Bulletin, July 31, 2009, available at www.shb.com/ newsletters/ICAB/ICAB73109.pdf.

219. Law No. 23511, Apr. 14, 1988, [LVI-C] A.D.L.A. 3321 (Arg.).

220. Law No. 25676, Nov. 27, 2002, B.O. $28-11-2002$ (Arg.).

221. $I d$. at art. 47.

222. Id. at art. 19 .

223. See Halabi, Corte Suprema de Justicia de la Nacion [CSJN] [National Supreme Court of Justice], Feb. 24, 2009, "Halabi, Ernesto C. Poder Ejecutivo Nacional (P.E.N.) - Ley 25.873," dto. 1563/04 s/ amparo ley 16.986 (Arg.).

224. Law No. 25873, Feb. 6, 2004, B.O. 30335 (Arg.); Law No. 1563/04, Nov. 9, 2004 (Arg.). 
ing that it violated the right to privacy of an undetermined number of Argentine citizens as well as most attorney-client privileged communications, including those between Halabi and his clients. $^{225}$

Both the lower court and the National Chamber of Appeals (NCA) accepted the petitioner's arguments and declared the law unconstitutional. ${ }^{226}$ The res judicata effect of their decisions was extended to "all telecommunications users" regardless of whether they had joined the court proceedings. ${ }^{227}$ In affirming the lower court's judgment, CSJN went further and asserted Halabi's status as a class action. Although filed by an individual citizen, Halabi involved the rights of a large group of "divisible individual interests" tied by common elements of fact and law. This, CSJN said, justified the aggregation of all individual claims into a single trial that would produce res judicata effects with respect to all. ${ }^{228}$ Individual damages, however, should be determined separately. ${ }^{229}$

CSJN acknowledged that, while no federal class action statute had been enacted in Argentina, the right to an effective judicial remedy ${ }^{230}$ set forth in Article 43 of the 1994 Constitution $^{231}$ gave the Court ample power to devise a suitable mechanism for the defense of collective rights. ${ }^{232}$ A remedy akin to Rule 23 of the U.S. Federal Rules of Civil Procedure (FRCP) ${ }^{233}$ was, according to the Court, appropriate in this case. ${ }^{234}$

CSJN identified four requisites for a claim, such as the one filed by Halabi, to proceed as a class action. First, there had to be a single or complex event producing harm to a significant group of individual rights (common elements of fact). Second, the claims asserted by the class had to be superior to the potential individual claims of each member (superiority). Third, the claims were prac-

225. See Halabi, Corte Suprema de Justicia de la Nacion [CSJN] [National Supreme Court of Justice], Feb. 24, 2009, "Halabi, Ernesto C. Poder Ejecutivo Nacional (P.E.N.) - Ley 25.873," dto. 1563/04 s/ amparo ley 16.986 (Arg.), at 1.

226. Id. at 2 .

227. Id.

228. $I d$. at 11 .

229. Id. at 7 , II 12 .

230. Id. at 8,12 .

231. Art. 43, Constitucion Nacional [Const. Nac.] (Arg.).

232. See Halabi, Corte Suprema de Justicia de la Nacion [CSJN] [National Supreme Court of Justice], Feb. 24, 2009, "Halabi, Ernesto C. Poder Ejecutivo Nacional (P.E.N.) - Ley 25.873," dto. 1563/04 s/ amparo ley 16.986 (Arg.), at 16. 233. FED. R. Civ. P. 23.

234. See Halabi, Corte Suprema de Justicia de la Nacion [CSJN] [National Supreme Court of Justice], Feb. 24, 2009, "Halabi, Ernesto C. Poder Ejecutivo Nacional (P.E.N.) - Ley 25.873," dto. 1563/04 s/ amparo ley 16.986 (Arg.) at 16. 
ticable only when filed in an aggregate fashion. Finally, the class had to be adequately represented..$^{235} \mathrm{CSJN}$ concluded that all four requisites were present in Halabi. ${ }^{236}$

In addition to the aforementioned prerequisites, the Court offered guidance on other elements that should be taken into account when dealing with potential aggregate cases in the future. This involved devising an adequate procedure for giving notice to potential class members so they can opt out or remain involved in the litigation. It also included the adoption of mechanisms geared to avoid the re-litigation of the same issues in different proceedings. ${ }^{237}$ Ideally, these and other aspects should be the subject of special legislation. Meanwhile, Argentine courts continue to rely on the principles set forth in Halabi, which only seem to address injunctive relief class actions and not those seeking monetary relief.

\section{Chile $^{238}$}

Unlike Argentina, where the strongest support for class actions has come from the courts instead of statutes, Chile has enacted a much more elaborate procedural scheme for class actions that gravitates around the Ley de Protección al Consumidor of 2004 (Consumer Protection Act, or CPA). ${ }^{239}$ Despite warnings of a potential surge in class action litigation fueled by the 2004 CPA amendment, ${ }^{240}$ only fifty-seven class action lawsuits were filed in Chile between 2004 and $2010 .{ }^{241}$ From this universe, almost eighty percent of the cases were filed in the courts of Santiago, the country's capital, ${ }^{242}$ and the majority referred to abusive commercial practices including the overcharging of fees for certain services, such as banking and retail transactions. ${ }^{243}$

235. Id. at 6 .

236. Id.

237. Id. at 10 .

238. For a more detailed description of the Chilean class action regime, see Conference Report, Martin Gubbins \& Carla Lopez, Stanford Law School, The Globalization of Class Actions Conference (Dec. 13-14, 2007), http://www.law. stanford.edu/display/images/dynamic/events_media/Chile_National_Report.pdf. See also Agustín Barroilhet, Class Actions in Chile (2011) (unpublished thesis, Stanford Program in International Legal Studies, Stanford University)(on file with author), available $\alpha t$ http://ssrn.com/abstract $=1995906$.

239. Law No. 19955, Julio 2, 2004, Diario Oficial [D.O.] (Chile) [hereinafter "CPA"].

240. Barroilhet, supra note 238 , at $20 \&$ n. 77 .

241. $I d$. at 17 .

242. Id. at $20 \& \mathbf{n} .78$.

243. Id. at 22 . 
The Chilean statute allows three types of procedural vehicles for the protection of consumer rights: collective actions filed on behalf of an identifiable group of consumers linked to a single defendant by a contract, ${ }^{244}$ collective actions for the defense of diffuse interests (unidentifiable groups of consumers), and individual actions. ${ }^{245}$

Both collective and diffuse interest actions may only be brought by three entities. First, the National Consumer Service (SERNAC), ${ }^{246}$ a public agency that is part of the Ministry of Economy, Growth and Reconstruction. ${ }^{247}$ In addition to its litigation role ${ }^{248}$ SERNAC is also charged with implementing consumer protection policies, leading public campaigns, and overseeing the activities of other consumer advocacy organizations. As most other public agencies, SERNAC obtains limited funding from the Chilean central government, making it difficult to accomplish most of its goals when coupled with the very ambitious agenda with which it has been charged. ${ }^{249}$

Consumer associations are the second type of entity with standing to pursue class actions in Chile. ${ }^{250}$ While private in nature, CPA requires consumer associations to meet some special requirements, including having been incorporated for at least six months prior to bringing any class action. Also, consumer associations are required to obtain express authorization from their members to litigate each case. ${ }^{251}$

By imposing such restrictions, the CPA has attempted to limit the involvement in class actions to organizations that can adequately represent consumers, not only because of their longstanding and stable relationships, and also because these organizations are subject to external oversight and have been vetted by SERNAC. The CPA has conversely discouraged the rise of a class action litigation industry, arguably fueled by opportunistic lawyers with little or no long-term commitment to the protection of consumer rights, but rather driven by the prospect of an early settlement that brings a large fee award.

244. See CPA at art. 50.

245. Id.

246. Id. at art. 51(1)(a).

247. Id. at art. 57.

248. See CPA at art. 53 B (CPA empowers SERNAC to continue acting on behalf of plaintiff even in those cases where the original plaintiff has withdrawn their claim).

249. See Barroilhet, supra note 238 , at 34 .

250. See CPA at art. 51(1)(b).

251. Id. at arts. 5-9. 
The only way plaintiffs can circumvent the requirement of acting through a legally established consumer protection association or through SERNAC is by reaching the numerosity threshold of fifty individuals with claims linked by common issues of fact and law. ${ }^{252}$ Subject to court approval in the certification stage, a group of fifty is given standing to act as representative plaintiff on behalf of the entire class, ${ }^{253}$ to appoint common counsel, ${ }^{254}$ and pursue the litigation all the way to its conclusion.

In a recent empirical study of class actions in Chile, Barroilhet found that while between 2004 and 2010 SERNAC has appeared as plaintiff in more cases than each of the other two authorized entities, its dominance was only by a slim margin. SERNAC appeared as plaintiff in only 36.8 percent of the cases, while consumer associations filed 35.1 percent, and the remaining 28.1 percent were brought by groups of more than fifty individuals. ${ }^{255}$ This is contrary to what one might predict given the ample powers vested in SERNAC with respect to the other two types of authorized plaintiffs.

CPA also gives judges an expanded role with respect to class actions. For example, judges may appoint lead counsel as a way to organize the litigation more efficiently. In addition, the judge can monitor the lead counsel's work throughout the proceedings and set her fees after taking into account the amount in dispute, as well as the economic capacity of the parties. ${ }^{256}$ Plaintiff's counsel is also subject to severe disciplinary sanctions should the judge find a claim to be frivolous. ${ }^{257}$ Unlike most Latin American jurisdictions where contingency fee agreements are expressly forbidden, ${ }^{258}$ Chilean lawyers are authorized to enter into these types of arrangements with their clients. As a default rule, however, the judge always retains the power to set or regulate attorney fees. ${ }^{259}$

Once a class action suit is filed, the judge has to review carefully whether the four prerequisites set forth in Article 52 of the CPA are met. These include the determinations of whether the plaintiff has standing, whether the alleged harm affects the diffuse or collective interest of a class, whether the complaint

252. Id. at art. $51(1)(\mathrm{c})$.

253. Barroilhet, supra note 238 , at 15.

254. See CPA at art. 54 B.

255. Barroilhet, supra note 238 , at 32.

256. $I d$. at art. 51(7).

257. Id. at art. $50 \mathrm{E}$.

258. See Gomez, supra note 2, at 296.

259. Barroilhet, supra note 238 , at 8 . 
includes the factual circumstances that affect the entire class or group, and whether the potential number of class members is so numerous that-in terms of a cost-benefit analysis-a class action proceeding is justified. ${ }^{260}$ In her determination, the judge has to take into account any evidence submitted by the defendant to counter the plaintiff's request for certification. ${ }^{261}$

Immediately after class certification is granted, a public notice shall be given ${ }^{262}$ so others potentially affected by the allegedly harmful event may join the litigation as representative parties. ${ }^{263}$ The public notice also sets the beginning of a thirty-day opt-out period for those who want to be expressly excluded from the general effects of any potential decision on the merits. ${ }^{264}$ Once the opt-out period is over, any outcome - either via judgment or settlement-will have res judicata effects not only for the parties, but erga omnes. ${ }^{265}$ Other managerial powers given to Chilean judges in handling consumer class actions are the possibility of creating sub-classes, ${ }^{266}$ the active encouragement of settlement throughout the proceedings, ${ }^{267}$ and the proposal and implementation of a system establishing the payment and disbursement of award monies among individual plaintiffs. ${ }^{268}$

Even though Chilean class actions are among the most thoroughly regulated in Latin America, their limited span to harms arising exclusively out of consumer contracts, coupled with the apparent lack of coordination between the provisions of the latter and the Code of Civil Procedure, ${ }^{269}$ pose an important barrier to their use. A more comprehensive, and arguably better, method to achieve a harmonized regulation of class actions might be one taken by Mexico in a recent comprehensive statutory reform passed in August of 2011, discussed in the following subsection.

\section{Mexico}

As described earlier, it was in Mexico where amparo suits

260. See CPA at art. 52.

261. Id.

262. All public notices shall contain the specific requirements set forth in CPA article 54 A. See CPA art. 54A.

263. Id. at art. 53.

264. Id. at art. $53(\mathrm{f})$.

265. Id. at art. $54 \mathrm{C}$.

266. Id. at art. $53 \mathrm{~A}$.

267. Id. at art. $53 \mathrm{~B}$.

268. Id. at art. $54 \mathrm{~F}$.

269. See generally Barroilhet, supra note 238 (asserting that CPA is a patchwork with little or no harmonization with the rest of Chile's procedural laws). 
were first allowed by the 1841 Yucatán Constitution as a way to ensure the protection of constitutional rights in a swift manner. ${ }^{270}$ Amparo suits eventually spread around the region and evolved into a popular, low-cost remedy that enabled judges to offer remedies for violations to fundamental rights mentioned by the constitution but lacking statutory protection.

By the late-twentieth century, collective amparos were the remedy of choice in many jurisdictions. ${ }^{271}$ The lack of regulation of procedural remedies against collective or mass harms helped amparo gain popularity. On the other hand, however, this also created a great deal of uncertainty and lack of uniformity with respect to the overuse of amparos, which became synonymous with shortcuts to quick, albeit not necessarily adequate, judicial rulings. ${ }^{272}$

Despite being the motherland of amparo protection, Mexico's entry into the group of countries with a class action statute has been somewhat delayed. In 1988, Mexico established an injunctive relief action of collective nature in its General Statute for Environmental Protection and Ecological Balance. ${ }^{273}$ Standing to file this action was vested in the General Prosecutor's Office, and individual victims were allowed to participate in the proceedings only as third-party interveners. ${ }^{274}$ While important, this environmental action was limited in scope and not suitable for obtaining monetary damages. ${ }^{275}$ In 1992 , a similar action was established by the Federal Consumer Protection Law. ${ }^{276}$ In light of the limited scope of these remedies, many litigants have still preferred to file amparo suits or, whenever possible, to export their claims for trial

270. See Constituctón de la República de Yucatán [Cons. Yucatán], de 1841 (Mex.).

271. See Const. Arg. (1994); Const. Bol. (1967); Constitução Federal [Const.] (Braz.) (1998); Const. Costa Rica (1989); Const. Pol. Repub. El Sal. (1983); Const. Guat. (1985); Const. Hond. (1982); Constitución Política de los Estados Unidos Mexicanos [Const.] (Mex.) (1917); Constitución Política de la República Nicar. [Const.] (1987); Const. Pan. (1983); Const. Para. (1992); Const. Peru (1993); Const. URu. (1984); and Const. Venez. (1999).

272. See Díaz, supra note 61; Santillán \& Galeas, supra note 61.

273. See Ley General de Equilibrio Ecológico y Protección al Ambiente [LGEEPA] [General Environmental Law], as amended, Diario Oficial de la Federación [DO], 4 de junio de 1992 (Mex.) [hereinafter LGEEPA].

274. Id.

275. Id.

276. Ley Federal de Protección al Consumidor [LFPC] [Federal Consumer Protection Law], as amended, Diario Oficial de la Federación [DO], 24 de diciembre de 1992 (Mex.) [hereinafter LFPC]. 
in foreign-mainly U.S.—courts. ${ }^{277}$

Following a regional trend set by Brazil, ${ }^{278}$ Argentina, ${ }^{279}$ and Colombia ${ }^{280}$ in expanding the scope of constitutional provisions to include group and representative litigation as a special category worthy of special legislation, on June 10, 2010, the Mexican Congress approved a constitutional amendment to Article 17 of the Federal Constitution. ${ }^{281}$ As amended, Article 17 gave Congress a special mandate to pass federal legislation-within a year-that would develop and regulate collective actions. ${ }^{282}$ Moreover, the amended provision declared collective litigation to be the exclusive jurisdiction of the federal courts, ${ }^{283}$ thus thwarting any potential jurisdictional conflict that might arise between state and federal courts.

On August 30, 2011, a decree regulating class actions (hereinafter, Class Actions Decree or CAD) was published in the Diario Oficial de la Federación ("DO"). ${ }^{284}$ CAD fulfills the constitutional mandate to regulate collective litigation in Mexico by amending seven federal statutes: the Federal Civil Procedure Code (CFPC), ${ }^{285}$ the Federal Civil Code (CC), ${ }^{286}$ the Federal Antitrust Law (LFCE), ${ }^{287}$ the Federal Consumer Protection Law (LFPC), ${ }^{288}$

277. See Gómez, supra note 2; Smith Kline \& French Lab. Ltd. v. Bloch, [1982] 1 W.L.R. 730 (CA 1982) (Lord Denning M.R.); and Robertson \& Speck, supra note 2.

278. See Constitução Federal [Const.] (Braz.) (1998).

279. See Const. Arg. (1994).

280. See Const. Colom. (1991).

281. Constitución Política de los Estados Unidos Mexicanos [C.P.] [Constitution], as amended, título Primero, Capítulo I, De los Derechos Humanos y Sus Garantías, art. 17, Diario Oficial de la Federación [DO], 10 de junio de 2010 (Mex.)(Reformada denominación por decreto publicado en el DO el 10 de junio de 2010) adición del párrafo tercero se publicó en el DO el 29 de julio de 2010.

282. Id.

283. $I d$.

284. See Decreto por el que se reforman y adicionan el Código Federal de Procedimientos Civiles, el Código Civil Federal, la Ley Federal de Competencia Económica, la Ley Federal de Protección al Consumidor, la Ley Orgánica del Poder Judicial de la Federación, la Ley General del Equilibrio Ecológico y la Protección del Ambiente, y la Ley de Protección y Defensa al Usuario de Servicios Financieros, Diario Oficial de la Federación [DO],30 de agosto de 2011 (Mex.) available at http:// dof.gob.mx/nota_detalle.php? codigo $=5206904 \&$ fecha $=30 / 08 / 2011$.

285. Código Federal de Procedimientos Civiles [CFPC] [Federal Civil Procedure Code], as amended, Diario Oficial de la Federación [DO], 9 de febrero de 2012 (Mex.).

286. Código Civil Federal [CC] [Federal Civil Code], as amended, Diario Oficial de la Federación [DO], 31 de agosto 1928 (Mex.).

287. Ley Federal de Competencia Económica [LFCE] [Federal Antitrust Law], as amended, Diario Oficial de la Federación [DO], 24 de diciembre de 1992 (Mex.) (hereinafter LFCE).

288. See LFPC, Ley Federal de Protección al Consumidor [Federal Consumer 
the Enabling Law for the Federal Judiciary (LOPFJ), ${ }^{289}$ the General Environmental Law (LGEEPA), ${ }^{290}$ and the Banking Savings Protection Law (DUSEF). ${ }^{291}$

As the Mexican reform is largely focused on procedural aspects, most of the new provisions are intended for inclusion in the Federal Civil Procedure Code (CFPC), which now incorporates a new section that contains forty-seven articles, titled "Libro Quinto: De Las Acciones Colectivas." The remaining six statutes amended by CAD basically incorporate residual provisions dealing with standing, federal jurisdiction, ${ }^{292}$ and the expansion of collective procedures to different categories of claims. ${ }^{293}$

Despite the apparent comprehensiveness of the Mexican reform, Article 578 of the CFPC expressly limits collective actions to claims involving consumer relations (including financial and securities fraud) and environmental harms. ${ }^{294}$ Similar to the approach taken by the Colombian ${ }^{295}$ and Brazilian ${ }^{296}$ statutes, article 580 of the CFPC distinguishes between diffuse rights, collective rights, and individual rights of collective incidence (individually homogeneous rights). ${ }^{297}$ The first two are "indivisible" and belong to an unidentifiable (diffuse) or identifiable (collective) category of individuals linked by common questions of fact or law. ${ }^{298}$ The latter are "divisible" but affect an identifiable category of people similarly situated with respect to the law. ${ }^{299}$

This classification has important implications for standing purposes and for the type of remedy that is allowed in each case.

Protection Law], as amended, Diario Oficial de la Federación [DO], 24 de diciembre de 1992 (Mex.).

289. Ley Orgánica del Poder Judicial de la Federación [LOPJF] [Enabling Law for the Federal Judiciary] as amended, Diario Oficial de la Federación [DO], 27 de mayo de 1995 (Mex.).

290. See LGEEPA, Ley General de Equilibrio Ecológico y Protección al Ambiente [General Environmental Law], as amended, Diario Oficial de la Federación [DO], 4 de junio de 1992 (Mex.).

291. Ley de Protección y Defensa al Usuario de Servicios Financieros [DUSEF]

[Banking Savings Protection Law], as amended, Diario Oficial de la Federación [DO], 18 de enero de 1999 (Mex.).

292. See LFPC at art. 53(V).

293. See LFCE at art. 38; LFPC, supra note 276, at art. 26; and CC, supra note 286, at art. 1934 bis.

294. See CFPC at art. 578.

295. See CONSTITUCIÓN POLÍTICA DE COLOMBIA [C.P.](1991).

296. See CONSTITUIÇÃO FEDERAL [C.F.] [CONSTITUTION] (Braz.), supra note 34.

297. See CFPC at art. 580.

298. Id.

299. Id. 
Because diffuse rights pertain to an unidentifiable group, their violation can be asserted by anyone without having to demonstrate a preexisting legal relationship between agent and victim. ${ }^{300}$ An example of a diffuse action would be one that sought reparations for harm to the environment. Any citizen could bring such an action. The remedy sought in diffuse right actions is usually of injunctive nature with no monetary damages. ${ }^{301}$

Collective rights' actions, on the other hand, presuppose a legal or contractual relationship between the alleged wrongdoer (service provider, product manufacturer, or seller) and an identifiable group of victims. Also, any claims need to be brought on behalf of that group. ${ }^{302}$ With respect to the type of remedies sought, collective actions may involve both injunctive and monetary relief to benefit the individual members of the group. ${ }^{303}$ Finally, individual homogeneous actions can also seek injunctive or monetary relief and be aggregated in light of their common origin. ${ }^{304}$ In both collective and individual homogeneous actions, there is a proposed numerosity threshold of thirty individuals for the claim to proceed in an aggregate fashion. ${ }^{305}$

Similar to Chile's CPA, ${ }^{306}$ CAD gives standing to a limited number of public entities, including the Office of the Attorney General ${ }^{307}$ and other special federal prosecutors with subject matter expertise on consumer, securities fraud, antitrust, and environmental issues. ${ }^{308}$ A duly registered and authorized civil association ${ }^{309}$ may also bring suit on issues directly related to their activities as described in their articles of association. ${ }^{310}$ In order to obtain FJC authorization, civil associations need to exist for at least one year $^{311}$ and are required to file an annual report with

300. Id. at art. 581(I).

301. Id.

302. Id. at arts. $581(\mathrm{II}), 582$.

303. $I d$.

304. See CFPC at art. 581(III).

305. Id. at art. 588(III).

306. See CPA.

307. See CFPC at art. 585(IV).

308. See $I d$. at art. 585(I) (including the Federal Prosecutor for Consumer Protection (FPCP), the Federal Prosecutor for Environmental Protection (FPEP), the National Commission for the Protection and Defense of Financial services Users and, and the National Antitrust Commission).

309. Id. at art. 619 (indicating that, because class representation is deemed to be of public interest, the associations have to register with the Federal Judicial Council (FJC)).

310. Id. at art. 585(III).

311. Id. at art. 620 (II). 
FJC and remain subject to its oversight. ${ }^{312}$ Finally, CAD also gives standing to a group of at least thirty individuals acting as party representatives of a class. ${ }^{313}$ As a way to ensure adequacy of representation, CAD subjects civil associations and party representatives to a particularly high standard, including rules on conflicts of interest, ${ }^{314}$ sanctions for filing frivolous claims, ${ }^{315}$ and violation of professional conduct. ${ }^{316}$

Perhaps the most important deterrent is the prohibition imposed on plaintiffs to pursue collective litigation as a way to obtain profit, political benefit, or in any manner inconsistent with antitrust regulations. ${ }^{317}$ Should a party representative breach the standards set forth in Article 586 of CAD, a judge may remove them, in which case the General Attorney's Office will assume the representation and continue with the litigation. ${ }^{318}$

Upon the filing of the complaint, there is a preliminary certification phase during which the judge, based on an assessment of the prerequisites set forth in Articles 587 and 588 of CAD, will determine whether the litigation should proceed in an aggregate fashion. ${ }^{319}$ Once the complaint is certified, notice is given to all potential members of the class so they can request judicial approval to opt in. ${ }^{320}$ In addition to its active involvement in the certification phase, the judge retains ample powers to promote ${ }^{321}$ and approve settlement, ${ }^{322}$ issue precautionary measures, ${ }^{323}$ direct the taking of evidence, ${ }^{324}$ and set the amount and set the allocation of attorney and court fees. ${ }^{325}$

Mexico's class action amendment will come into force six months after its publication in the Official Gazette, which means that no cases will be filed until January or February of 2012. Only then will we be able to assess whether the statutes are able to

\footnotetext{
312. Id. at art. 623 .

313. Id. at art. 585(II).

314. Id. at art. 586(II).

315. $I d$. at art. 586(III)

316. $I d$. at arts. 586(I), (V).

317. Id. at art. 586(IV).

318. Id. at art. 586.

319. Id. at arts. $587-88,590$.

320. Id. at arts. 591, 593-94.

321. Id. at arts. 595-96.

322. Id.

323. Id. at arts. 611-12.

324. Id. at art. 598.

325. Id. at art. 618 .
} 
fulfill their promise of expanding the protection of individual and group rights, and effectively facilitating access to justice.

\section{Conclusion: A NEW Light SOURCE FOR THE MOTH?}

In a previous article, ${ }^{326}$ I used the metaphor of migratory birds to describe the behavior of Latin American parties who would either travel north, to the United States, or stay south in their own courts, depending on what incentives were available to them. ${ }^{327}$ Similarly, an oft-cited phrase by an English judge in a 1982 judicial decision ${ }^{328}$ equated foreign plaintiffs to "moths" being attracted to the "light" of the United States courts. ${ }^{329}$

Until recently, challenges faced by Latin American disputants in their home forums, coupled with the incentives offered by the legal system of the United States, have given credibility to these colorful metaphors. An emerging trend in Latin America, however, has the potential to help tilt the balance in the other direction. As described in this article, the tendency in Latin America seems to be in favor of expanding the procedural protection of individual and collective rights through the establishment of different forms of collective litigation, including class actions.

This movement, albeit timid, shows that the policy debate about class actions and other forms of group litigation has reached the necessary maturity level for the legal machinery to react and provide local protection against collective harms. The new Latin American class action statutes and related legislation are a step in the right direction. Nonetheless, some of these laws have left out a number of key aspects including representation issues, certification requirements, opt-in and opt-out procedures, procedural safeguards, punitive and catastrophic damages, and litigation finance.

Some of these deficiencies may be overcome with the help of creative judges and counsel in the short term, or eventually by additional legislation geared to fine-tune the foundations set forth by the current statutory framework. There is also a dire need for more empirical research on the use of class actions and other mechanisms in Latin America. Only by looking at how the law operates on the ground will one be able to assess whether the new

326. See Gómez, supra note 2.

327. Id. at 300 .

328. Smith Kline \& French Laboratories, Ltd. v. Bloch, [1983] 2 All E.R. 72, 74, 1 W.L.R. 730 (C.A. 1982) (Lord Denning M.R.).

329. Id. ("As a moth is drawn to the light, so is a litigant drawn to the United States. If he can only get his case into their courts, he stands to win a fortune."). 
framework has indeed contributed to shift the incentives and persuaded Latin American litigants to stay "south" in their own courts, or to be attracted by these new sources of light.

Meanwhile, the writ of amparo and other similar devices geared to obtain declaratory and injunctive relief will continue to serve as palliative until the official laws catch up with the needs of those affected with large-scale accidents and other harms, including those arising out of defective products and faulty services. 
